\title{
Notes
}

\section{THE CONSTITUTIONALITY OF TEACHING AND PERFORMING SACRED CHORAL MUSIC IN PUBLIC SCHOOLS}

\begin{abstract}
FAITH D. KASPARIAN
The imposition of religion on children in public schools is a violation of the doctrine of separation of church and state. To compel children in a public school to sing Christian devotional music is tantamount to imposing religious practice on children. ${ }^{1}$

Singing religious songs as a class assignment . . . is not a religious exercise to be equated with classroom prayers or Bible readings. ... 'Public schools are not required to delete from the curriculum all material that may offend religious sensibility.' If someone will sound an A, let us sing "A men!" to that. ${ }^{2}$
\end{abstract}

\section{INTRODUCTION}

The First A mendment to the Constitution states "Congress shall make no law respecting an establishment of religion." ${ }^{3}$ The ultimate purpose of the Establishment Clause, and of the First A mendment generally, is to protect the freedom of individual conscience, "to guard and respect that sphere of inviolable conscience and belief which is the mark of a free people." ${ }^{4}$ Because

1. A my R. Scheinerman, Religious Music at School, WASH. PoST, Nov. 21, 1995, at A 16 (letter to editor).

2. James Kilpatrick, Let Choir Sing "Amen!" to Three Rays of Common Sense, StA TE J.-REG. (Springfield, III.), O ct. 24, 1995, at M 1 (quoting J. Thomas Greene, District Judge, U tah).

3. U.S. CONST. amend. I.

4. Lee v. Weisman, 505 U.S. 577, 592, 605 (1992); see also Wallace v. Jaffree, 472 U.S. 38, 49 (1985) (“. . . the First A mendment was adopted to curtail the power of Congress to interfere with the individual's freedom to believe, to worship, and to express himself in accordance with the dictates of his own conscience."); School Dist. v. Schempp, 374 U.S. 203, 226 (1963) (arguing that "it is not within the power of government to invade that . . . inviolable citadel of the individual heart and mind"); Everson v. Board of Educ., 330 U.S. 1, 8-14 (1947) (chronicling background and environment of period in which constitutional language was adopted and citing James Madison's argument in oppo- 
public schools are uniquely positioned to shape the development of the individual conscience, Establishment Clause controversy involving public schools has been especially contentious. ${ }^{5}$ The arena of debate about what can take place in public schools has been called the "central battleground" for Establishment Clause conflict because the debate over "what teachers can teach, what books may be used, what songs sung ... strikes at the heart of many families' sense of spiritual freedom." 6

As the opening quotations illustrate, there is considerable debate as to whether the use of sacred choral music ${ }^{7}$ in public schools violates the Establishment Clause. This debate revives the historic conflict surrounding the relationship between music and religion. The conflict is not new; the locale of the conflict has simply changed from worship services to public schools. Throughout history, religious leaders have questioned the appropriateness of using sacred music in worship services. More recently, school administrators have questioned the appropriateness of teaching and performing sacred music in public schools.

Music is a powerful medium that has the capacity not only to create and to express emotions, but also to evoke powerful responses from its audience. ${ }^{8}$ It is an art that "reaches the emotions

sition to Virginia's tax levy for the establishment of a state church: "the best interest of a society required that the minds of men always be wholly free"); Laura UnderkufflerFreund, The Separation of the Religious and the Secular: A Foundational Challenge to First A mendment Theory, 36 WM. \& MARY L. REV. 837, 958-59 (1995) ("The protection of freedom of conscience lay at the base of two great and emerging principles: free exercise of religion and the destruction of religious establishment by government. . . [R ]eligious establishments by government were seen as potentially corrupting . . . to individuals, who would be forced to act in ways contrary to the dictates of conscience in order to obtain public power or benefits. . . ." ); id. at 961 ("[T] $[$ he protection of conscience was imperative."); id. at 891 ("Of all the 'fundamental rights' heralded during the Founding Era, calls for freedom of conscience were the most insistent and the most intense.").

5. See, e.g., Edwards v. A guillard, 482 U.S. 578, 583-84 (1987) (recognizing Court's vigilance in monitoring compliance with Establishment Clause particularly in elementary and secondary schools given impressionability of students and that attendance is involuntary).

6. Nancy Gibbs, A merica's Holy War, TIME, Dec. 9, 1991, at 61, 65.

7. "Sacred" is a musical term of art that refers to music with religious content, as opposed to "secular" music, which has no religious content.

8. See Arnold Perris, Music as Propaganda 138 (1985). Even the Supreme Court has commented on the power of music:

Music is one of the oldest forms of human expression. From Plato's discourse in the Republic to the totalitarian state in our own times, rulers have known its capacity to appeal to the intellect and to the emotions, and have censored musical compositions to serve the needs of the state.... The Constitution 
easily, often (always?) ahead of intellectual awareness." ${ }^{9}$ A ccordingly, incorporating music into a ceremony, such as a worship service or the inauguration of a political leader, can make that ceremony more evocative, more meaningful. ${ }^{10} \mathrm{~F}$ or centuries, however, religious leaders have had conflicting views concerning the use of sacred music within the worship service. ${ }^{11}$ This conflict stems from the inherently dual nature of vocal music. Vocal music can at once be a vehicle for the promotion of a textual message and an independent aesthetic entity that in no way depends on the performer's or the listener's endorsement of the textual message. ${ }^{12}$ Over fifteen centuries ago, St. A ugustine recognized that

prohibits any like attempts in our own legal order. Music, as a form of expression and communication, is protected under the First A mendment.

Ward v. Rock A gainst Racism, 491 U.S. 781, 790 (1989).

9. PERRIS, supra note 8 , at 6 .

10.

M usic began by serving communal purposes .... It has continued to be used as an accompaniment to collective activities; as an adjunct to social ceremonies and public occasions. .... In our society, one cannot imagine a Coronation or a State funeral taking place in the absence of music. . . . Music has the effect of intensifying or underlining the emotion which a particular event calls forth, by simultaneously co-ordinating the emotions of a group of people.

Anthony Storr, Music and the Mind 23-24 (1992).

11. See PERRIS, supra note 8 , at 155 (referring to conflict between religious leaders and sacred music composers: "[N]0 other genre of Western [m]usic documents such a long and strenuous contest between artist and 'ruler' for the attention of their audience.").

12. See Musicage: Cage Muses On Words Art Music 69 (Joan Retallack ed., 1996) [hereinafter MUSICAGE] ("[S]ound sometimes becomes so powerful that one can put meaning aside. A nd vice versa."); STORR, supra note 10, at 75 ("Stravinsky strongly objected to the notion that a piece of music is a transcendental idea expressed in terms of music . . . . He said that 'A new piece of music is a new reality' . . . 'music expresses itself'. . . '[the composer] can say nothing whatever about meanings.'"); JEAN-JACQUES NATTIEZ, MUSIC AND DISCOURSE 126 (Carolyn A bbate trans., 1990) ("For users of music, composers, performers, and listeners, all participants in a 'total musical fact,' musical material will establish connections to their lived experience and to the exterior world. . . . But musical material's play of forms is itself a semiological system, inasmuch as it functions and develops independently of the extrinsic meanings conveyed . . ..").

In discussing the dual nature of sacred music specifically, it has been noted that music originally written for worship service can become admired for its aesthetic identity and devalued for its religious significance. See PERRIS, supra note 8 , at 148 . The requiem Masses of Mozart, Berlioz, and Fauré were originally written for "immediate liturgical use" but are today "thought of as secular concert works and are so heard by the public." Id. at 149; see also STORR, supra note 10, at 22:

To play the hymn 'A bide With $\mathrm{Me}^{\prime}$ at football matches is in dubious taste; but those who join in singing it feel an enhanced sense of joint participation, even if they do not believe the words which they are singing, or subscribe to the Christian beliefs which the hymn expresses. .. . Music's power to fan the flame of piety may be more apparent than real; more concerned with enhancing 
sacred music could be both secular and religious, and agonized over that duality:

[S]ometimes I feel that I treat [sacred music] with more honor than it deserves. I realize that when they are sung, these sacred words stir my mind to greater religious fervor and kindle in me a more ardent flame of piety than they would if they were not sung .... . But I ought not to allow my mind to be paralyzed by the gratification of my senses, which often leads it astray. . . . I waver between the danger that lies in gratifying the senses and the benefits which, as I know from experience, can accrue from singing. ... I I am inclined to approve of the custom of singing in church, in order that by indulging the ears weaker spirits may be inspired with feelings of devotion. Y et when I find the singing itself more moving than the truth which it conveys, I confess that this is a grievous $\sin \ldots$. $^{13}$

Therefore, while religious leaders have recognized the unique power of sacred music to instill religious passion, they have simultaneously feared that the secular and sensual pleasure of the music will take precedence over the sacred text it conveys. ${ }^{14}$ Simply put, "[t]he arts are a powerful but dangerous ally to religion: They can carry the message, but they can also run away with it." ${ }^{15}$

group feeling within the congregation than with promoting the individual's relation with $\mathrm{G}$ od.

13. St. A ugustine, The Testimony of St. Augustine, in PIERO WEISS \& RICHARD TARUSKIN, MUSIC IN THE WESTERN WORLD 29, 32 (1984) (emphasis added). A modern version of the debate between music and religion arose within the Emmanuel Church of Boston, famous for its tradition of performing, as Bach had intended, a complete Bach cantata as a part of the regular Sunday worship service. See Richard Dyer, Emmanuel Revives an Ancient Battle: Music vs. Religion, BOSTON GLOBE, July 23, 1993, at 39. E mmanuel was recognized in the 1970s for being the only church other than Bach's own church in Leipzig to have performed a complete cycle of Bach's sacred cantatas. See id. In 1993, E mmanuel's music program "found itself on the firing line" of the "immemorial uneasy relationship between the arts and religion" when critics accused the music program of "worshipping Bach rather than God." Id.

14. See PERRIS, supra note 8 , at 124 :

Music in all worship is expected to heighten the desired emotional effect in the listener, to emphasize the ritual text, especially certain significant words, and to focus the worshipper's attention on the rite. But the danger of so sensuous a phenomenon as music is that it may be more seductive than the rite itself, and that the musicians may evoke more interest than the priests. If the music in the worship service is "entertaining," is the religious ambience destroyed? ... In any one culture are there two kinds of musical expression, one identified as sacred, and the other as nonsacred and appropriate only for secular occasions?

15. Dyer, supra note 13 , at 39 . 
The tension between music and religion raises important questions. Is a song with a sacred text only a vehicle for religious worship and divine praise, or an independent secular aesthetic entity as well? Once a sacred text is set to music in the form of a song, can either element of the song-text or music-be isolated or viewed as more powerful than the other? Can one sing a sacred song, recognizing the important aesthetic relationship between music and text, without engaging in a religious exercise? These questions remain when the locale of the tension shifts from worship service to public schools. In the public school context, however, the fear is not that the secular pleasure of the music will take precedence over the sacred text, but rather that the sacred text will take precedence over the music, with unconstitutional Establishment Clause ramifications. ${ }^{16}$

Discerning the Establishment Clause ramifications of using sacred choral music in public schools is difficult because the Supreme Court has never addressed the issue ${ }^{17}$ and because, as courts and commentators have noted, the body of Establishment Clause precedent is confusing at best. ${ }^{18} \mathrm{~N}$ evertheless, the Court's

16. A Ithough there are also ramifications to the use of sacred choral music in public schools under the Free Exercise Clause, this Note will not address the Free Exercise Clause and will focus solely on the Establishment Clause.

17. See, e.g., Bauchman v. West High Sch., 900 F. Supp. 248, 253 (D. U tah 1995) ("Neither the Supreme Court nor the Tenth Circuit have had occasion to determine whether choral singing at a graduation exercise constitutes a prayer which would implicate the First A mendment Establishment Clause.").

While some lower courts have confronted the Establishment Clause ramifications of teaching sacred choral music in public schools, see infra Section II.B, their analysis of issues has often been perfunctory and has not been helpful in providing guidance to local decisionmakers. See infra notes 252-60 and accompanying text (discussing Doe v. Duncanville Indep. Sch. Dist., 70 F.3d 402, 404-07 (5th Cir. 1995) (accepting choir director's unrelated justification for maintaining sacred piece as choir's "theme song" and not addressing certain facts-choir's singing of song at end of class on Fridays and on bus rides after competition-that may alter the blanket statement that "[a]ll parties recognize that the Establishment Clause does not prohibit DISD choirs from singing religious songs as part of a secular music program, in accord with School District of A bington Township v. Schempp.") (citations omitted)); see also Robert M. O'Neil, Who Says Y ou Can't Pray?, 3 VA. J. SoC. PoL'Y \& L. 347, 362 (1996) (arguing that "the issue of religious music and school choirs... deserves closer scrutiny than the Duncanville Court provided .....").

18. This confusion stems from seemingly inconsistent decisions, see infra note 192 and accompanying text, and from varying analytical approaches, see infra Section II.A. See also Edwards v. A guillard, 482 U.S. 578, 639 (1987) (Scalia, J., dissenting) (chastising the Court's "embarrassing Establishment Clause jurisprudence"); D oe v. Duncanville Indep. Sch. Dist., 70 F.3d 402, 405 (5th Cir. 1995) ("[M ]odern Establishment Clause jurispru- 
Establishment Clause precedent may still be instructive insofar as it illustrates a distinction between constitutionally permissible and impermissible public school activities. The Court has consistently held state-directed ${ }^{19}$ "religious exercises" in the public schools, such as state-directed prayer $^{20}$ and state-directed devotional Bible reading, ${ }^{21}$ to be unconstitutional. On the other hand, the Court has implied that state-directed study of religion or the Bible, as part of a secular program of education, would be constitutional. ${ }^{22}$ Specifically, in School District of Abington Township $v$. Schempp, ${ }^{23}$ the Court indicated that teaching the Bible as literature would be constitutional. ${ }^{24}$ Presumably, if teaching the Bible as literature would be constitutional, so too would teaching sacred choral music, ostensibly "the Bible as song." Unfortunately, the Court's dictum in Schempp is broadly phrased and does not provide specific guidance. ${ }^{25}$ Therefore, the difficulty lies in distinguishing a "religious exercise" from a secular study of religion.

dence is rife with confusion"); Doe v. Duncanville Indep. Sch. Dist., 994 F.2d 160, 166 n.7 (5th Cir. 1993) (noting the "Supreme Court's confusing and confused Establishment Clause jurisprudence"); O'Neil, supra note 17, at 349 ("The boundaries of permissible activity under the Establishment Clause remain elusive in many important areas."); Underkuffler-Freund, supra note 4, at 838 (describing Court's Free Exercise and Establishment Clause precedent as "jurisprudence of complex, conflicting, and often undulating principles"); id. at 848 (reiterating that Free Exercise and Establishment Clause precedent is a "body of jurisprudence of perhaps unparalleled contradiction and confusion"); Kilpatrick, supra note 2, at M 1 ("In the whole broad field of constitutional law, no area is murkier than the area surrounding the First A mendment's Establishment Clause"); Opinion, Sound West High Ruling, SALT LAKE TRIB., June 6, 1996, at A 12 (referring to "constitutional thicket").

19. By the term "state-directed," this Note refers to an activity that is led or directed through state action. A stated-directed activity could involve a public school teacher, administrator, or policy.

20. See Engel v. Vitale, 370 U.S. 421, 424 (1962).

21. See School Dist. v. Schempp, 374 U.S. 203, 205 (1963).

22. See id. at 225 ("Nothing we have said here indicates that such study ... may not be effected consistently with the First A mendment.").

23. 374 U.S. 203 (1963).

24. The Schempp Court explained:

It certainly may be said that the Bible is worthy of study for its literary and historic qualities. Nothing we have said here indicates that such study of the Bible or of religion, when presented objectively as part of a secular program of education, may not be effected consistently with the First A mendment.

Id. at 225. The Schempp Court distinguished studying the Bible as literature or history from the state-directed, devotional Bible reading found unconstitutional in the case, holding that the latter devotional use as a "religious exercise." Id. ("[T] The exercises here do not fall into those categories. They are religious exercises . . . .").

25. See id. 
L ack of clear legal standards has resulted in widespread public confusion over what constitutes a constitutional use of material with religious content in the public schools. Such confusion threatens the use of sacred choral music in the public schools because it has the potential to create, and in some cases has already created, a chilling effect on the use of all "religious" materials for teaching purposes. This chilling effect is dangerous because music education, particularly performance-based education, is a necessary component of the public school curriculum, and sacred choral music is an integral part of a complete and historically accurate music education. ${ }^{26}$ Removal of sacred music from the performance repertoire would deprive students of a complete educational experience by presenting an erroneous view of the Western music tradition.

This Note confronts the Establishment Clause issues involved in using sacred choral music in the public schools-and hence confronts the questions inherent in the dual nature of vocal music-by analyzing three hypothetical fact patterns. ${ }^{27}$ In analyzing similar Establishment Clause fact patterns, the Supreme Court has focused on two factors- the purpose and the effect of the use. However, analysis of the hypotheticals in this Note reveals that the most instructive factor in resolving these E stablishment Clause questions is not the purpose- not the subjective motivation of the individual who selects the sacred repertoire-but rather, the effect of using the music. Further, in determining that effect, the Court has focused on the context of the use. In analyzing the teaching and performing of sacred choral music, the following factors will likely contribute to a court's analysis of context: the teaching style of the choir director, including statements made during rehearsal; the site and time of year of a concert; the placement of particular selections within the order of the program; the presence of program notes ${ }^{28}$ explaining the musical significance of works performed; and the nature of performative artifice-the extent to which the performance underscores the nature of the music as independent aesthetic entity. ${ }^{29}$

26. See infra Part I.

27. These hypotheticals are partially modeled on aspects of lower court cases addressing the constitutionality of teaching and performing sacred choral music in public schools. See infra Part III.

28. "Program notes" is a musical term of art that refers to a prose description in the concert program of the musical significance and relevant musical features of a particular work.

29. Context is crucial, not only from a legal perspective, but also from a musical 
W ith this analytical framework in mind, this Note argues that, in true teaching or performance contexts, the use of sacred choral music in public schools is not only educationally necessary but constitutionally permissible. Part I of this Note illustrates the widespread public confusion over what is permissible activity in the public schools, depicts the chilling effect that results from such confusion, and explains the danger of such a chilling effect by articulating pedagogical justifications for teaching and performing sacred choral music in public schools. Part II of this Note discusses relevant Establishment Clause precedent and proposes an analytical framework for evaluating the Establishment Clause ramifications of teaching and performing sacred choral music in the public schools. Using this framework, as well as Supreme Court and lower court precedent, Part III considers, through three hypothetical fact patterns, the constitutionality of using sacred choral music in varying public school contexts.

\section{The Potential Elimination of Sacred Choral Music FROM PUBLIC SCHOOLS}

Since the Supreme Court has made no definitive legal statement, sacred choral music may be unnecessarily eliminated from public school curricula as a result of general public confusion over what uses of materials with religious content are permissible in the nation's public schools. ${ }^{30}$ Throughout the country, surprising anec-

perspective. A musical work is not created merely by the composer's writing of the music and setting of that music to text; rather, the performer's interpretation and the listener's perception contribute to the creation and meaning of the musical work. A ccordingly, the context of a particular performance, including the performer's interpretation of the music, is as much an aspect of the aesthetic entity as the music written in the score. See NATTIEZ, supra note 12, at ix-x, 72 (endorsing "holistic vision" of music, called musical semiology, stating that a musical work is also "constituted by the procedures that have engendered it (acts of composition), and the procedures to which it gives rise: acts of interpretation and perception" and positing that a musical work is not "wholly 'produced' unless it has been played" and that the compositional process extends until the performance is complete). Composer and aesthetic philosopher John Cage embraces this concept of meaning-as-use and argues that the listener then contributes by enacting the meaning through its use. See MUSICAGE, supra note 12, at 67. Cage explains, "I'm frequently now in the situation of having to listen to music which I've already written, which is finished as far as I'm concerned. But when I haven't made it clear in many ways what it is, it becomes of course the way that it is made by other people. . . I I don't know anything to expect in relation to it ...." Id. at 200. A rguably, a composer can never make clear what an aesthetic entity is, especially an aesthetic such as vocal music which has-at least-a dual identity.

30. For example, in a December 1994 CBS News/New Y ork Times poll, the majority 
dotes are plentiful. A Maryland school teacher told a kindergarten student that she could not sing a verse of a religious song to her classmates, even though the teacher had asked each child to share a favorite song with the class. ${ }^{31}$ A nd an Illinois school teacher, upon finding the word "God" in a phonics textbook, instructed her class of seven-year-olds to cross it out, explaining that it is illegal to mention God in a public school. ${ }^{32}$

Recognition of the problem posed by this confusion has come from many sources. A survey of the M usic Educators Journal, a publication of the Music Educators National Conference (MENC), reveals numerous articles from the 1960s to the present that recognize the confusion over what is permissible and support the use of sacred music in public schools. ${ }^{33}$ Government officials, including U nited States Secretary of Education Richard W. Riley, ${ }^{34}$ A cting Solicitor General Walter Dellinger, ${ }^{35}$ and A ugust Steinhilber,

of all A mericans-55\% - did not know that a child's right to pray privately in school is constitutionally protected. See Statement by U.S. Secretary of E ducation Richard W. Riley regarding "Religion in Public Schools: A Joint Statement of Current Law," A pril 13, 1995; see also American CIVIL Liberties Union, Religion in the Public SChools: A JoInt Statement of CuRRent LAW 1 (1995) ("Some say ... that the law is so murky that school officials cannot know what is legally permissible.").

31. See Press Briefing, Statement by Secretary of Education Richard W. Riley, July 12, 1995 [hereinafter Riley Press B riefing].

32. See Gibbs, supra note 6 , at 61 .

33. See MENC, Religious Music in the Schools, MUSIC EdUCATORS J., July 1996, at insert ("The First A mendment does not forbid all mention of religion in the public schools...."); MENC, Religious Music in the Schools, MUSIC Educators J., Nov. 1984, at 28; Rebecca Grier, Sacred Music in the Schools: An Update, MusIC EduCATORS J., Nov. 1979, at 48; John Aquino, Can We Still Sing Christmas Carols in Public Schools?, MUSIC EdUCATORS J., Nov. 1976, at 71; Donald Meints, Are We Violating the Constitution?, MUSIC EDUCATORS J., Jan. 1965, at 62 ("In the light of recent decisions by the United States Supreme Court, some choral music directors in high schools throughout the country are confused about the place of sacred choral music in the public school music program."); Charles M. Fisher, The Place of Religious Music in the School Curriculum, MUSIC EDUCATORS J., Nov. 1966, at 66 (noting that even much secular music is "religious" in the broad sense of the word and that such music should not be excluded from public school curriculums); Benjamin J. Novak, Building Ties Between School and Church Music, MusiC EduCATORS J., Sept.-Oct. 1963, at 119 ("It is difficult to argue validly against the inclusion of some church music as part of a balanced musical repertoire for all schools.").

34. See Riley Press Briefing, supra note 31 ("[T] $[$ here's an awful lot of confusion out there. A nd I see it and hear it.").

35. See Laurie Goodstein, School Prayer Directive May Not Settle All Cases; Many Religious Disputes Fall in Gray Zone, WASH. PoST, July 15, 1995, at A 1 (quoting A cting Solicitor General Dellinger's statement that "the president believes it is important that we reduce the amount of confusion and misinformation that currently surrounds the sub- 
general counsel for the National School Boards A ssociation, have also acknowledged confusion over the relationship between religion and public schools. A nd at least one legal commentator, recognizing the confusion, has opposed the use of sacred choral music in public schools, proposing guidelines for religious holiday observances in public schools that would eliminate sacred music from such programs. ${ }^{37}$

R ecently, the President and numerous legal organizations have attempted to dispel the myths and to alleviate the confusion by issuing statements concerning religion and the public schools. ${ }^{38}$ Perhaps the most wide-reaching was a four-page directive issued, at the instruction of the President, by the U nited States Department of Education. ${ }^{39}$ In A ugust of 1995, Secretary Riley sent this directive to the superintendents of every school district in the U nited States. ${ }^{40}$ The directive summarizes the Schempp Court's implication that state-directed study of religion, as part of a secular program of education, is constitutional and supports, in general terms, the use of sacred choral music in public school curricula:

Public schools may not provide religious instruction, but they may teach about religion, including the Bible or other scripture: the history of religion, comparative religion, the Bible (or other

ject").

36. In 1995, the Washington Post quoted Steinhilber's complaint that: "There was a time when most of the questions I got were on [AIDS] issues. ... Then it moved to drugs and drug testing, then sexual harassment. Now, number one is religion." Id.

37. This commentator has argued, "Most hymns and many carols are prayers or other expressions of worship set to music." Note, Religious-Holiday Observances in the Public Schools, 48 N.Y.U. L. REV. 1116, 1144 n.174 (1973). The proposed guidelines state:

The content of any such programs must relate only to the secular aspect of the holiday. ... seasonal songs such as "E aster Parade," "Over the River and Through the Woods," "Deck the Halls," "White Christmas," etc., may be performed. .... Hymns, songs, carols ... . expressing reverence to God, J esus, Buddha, M ohammed or any other religious prophet or leader, may not be prepared or performed as part of a holiday observance. ... The atmosphere and trappings must be free from any element of devotional setting. Processionals, clerical robes, candles or other church-like or reverential lighting effects, scenery or costumes may not be used.

Id. at 1144 (footnotes omitted).

38. See, e.g., Remarks by the President on Religious Liberty in A merica, July 12, 1995, at James Madison High School, Vienna, Va. [hereinafter Clinton Religious Liberty Remarks]; The Freedom Forum First Amendment Center, A Parent's Guide to Religion IN THE PUBLIC SChOOLS (1995) [hereinafter PARENT'S GUIDE to Religion]; ACLU, supra note 30 .

39. See Department of Education Directive, A ug. 10, 1995.

40. See Cover letter included with Department of Education Directive, A ug. 10, 1995. 
scripture)-as-literature, and the role of religion in the history of the United States and other countries all are permissible public school subjects. Similarly, it is permissible to consider religious influences on art, music, literature, and social studies. ${ }^{41}$

The statements of other organizations similarly support teaching and performing sacred music in public school curricula as part of an objective program of secular education. ${ }^{42}$ A lthough some officials feel that the Department of Education directive has solved the confusion, ${ }^{43}$ controversies and litigation have unfortunately continued. ${ }^{44}$ As Dellinger explains, despite Presidential efforts,

41. Department of Education Directive, A ug. 10, 1995.

42. See, e.g., Clinton Religious Liberty Remarks, supra note 38, at 7-8:

The First A mendment does not-I will say again-does not convert our schools into religion-free zones. ... Some school officials and teachers and parents believe that the Constitution forbids any religious expression at all in public schools. That is wrong. Our courts have made it clear that that is wrong. ... . Teachers can and certainly should teach about religion and the contributions it has made to our history, our values, our knowledge, to our music and our art in our country and around the world .....

See also PARENT'S GUIDE TO RELIGION, supra note 38, at 7:

Sacred music may be sung or played as part of a school's academic program. School concerts that present a variety of selections may include religious music. The use of music, art, drama, or literature with religious themes is permissible if it serves a sound educational goal in the curriculum, but not if used as a vehicle for promoting religious belief.

See also Rutherford inst., Recognition of Religious holidays in Public SCHOOLS 2 (1993).

43. See Tamara Henry, Religion's Place in Public Schools: Holidays Bring Issue to the Fore, USA TODAY, Dec. 7, 1995, at 5D ("A ugust Steinhilber vigorously disagrees that wide confusion still exists. A general counsel for the National School Boards A ssociation, he says traditionally his office is flooded with calls beginning with $\mathrm{H}$ alloween through Christmas. 'So far, I don't think I've gotten two calls,' he says."). This same article notes a recent anecdote involving an art teacher in Alto, Tex. The teacher fumed when a seventh-grade student drew a picture of Santa and Jesus, and upon tearing up the sketches told the student, "Y ou have a problem!" Id.

44. A post-directive letter to the editor of the St. Petersburg Times demonstrates the continued controversy:

I strongly object to the $M$ arch 26 letter that so unfairly criticized the northwest Elementary music director for including two 'religious songs' during a district concert recently. For the objector's information, the R eligious Freedom Restoration A ct was signed into law over two years ago by President Clinton, and the objectionable songs would certainly come within the 'incidental effect' of the RFRA. To charge the music director with a 'flagrant attempt to religiously indoctrinate' and 'abuse his position to flout the establishment clause of the First A mendment' is both obnoxious and idiotic.

U rban Meyer, Letter to Editor, Critic of School Concert Was Uninformed, Rude Series, St. Petersburg Times (Fla.), A pr. 1, 1996, at A 1. See also supra notes 1-2 and accompanying text (demonstrating post-directive debate); Priscilla H. Crago, Religious Songs A re Prayers Set to Music, TIMES UNION (A Ibany, N.Y.), Nov. 16, 1995, at A 14 (quoting Albany, N.Y., parent who asserts: "[R]eligious songs are merely organized prayers set to 
"[t]here will always, in an area like this, be cases in the margin where controversy will continue." 45 Continued controversy stems from the highly sensitive and personal nature of the issue, from the Court's silence on the constitutionality of using sacred choral music in public schools, and from general confusion in Establishment Clause precedent.

W ith the lack of a direct statement from the Supreme Court, continuing confusion and controversy have the potential to create, and in some cases have already created, a chilling effect on the use of sacred choral music in public schools. Music educators receive pressure from parents and administrators to eliminate sacred music from the curriculum. O ne retired elementary music administrator has aptly described the situation:

Music teachers have enough pressures today without the repeated beating over what religious music is or isn't safe to program for specific school holiday observations, for regular curriculum use, or for artistic and historical use. . . . Each holiday brings its own perky patrons peeking around the back side of the practice piano to see if we are about to program too much/little to satisfy individual and varied expectations of how they want each holiday honored/ignored. Add to this group the word warriors who pounce on the phone to scorch our inner ear when they discover that the song we taught yesterday had the word spirit in it . . . . In many areas, religious music used in the schools, absent from clearly understood court-case related policy outlining its appropriate and acceptable use, is a gigantic kettle of boiling water in search of a scaldee. ... Now where were we? Oh yes, teaching children music. ${ }^{46}$

music. Not only has the Supreme Court banned prayers in public schools, but the Bill of Rights does not allow establishment of a particular religion."); Goodstein, supra note 35, at A 6 (quoting an attorney who defends the rights of students "to present the full musical repertoire" who stated, "Whoever heard of a choir that can't sing anything from the Renaissance, most things from the Baroque period, or for that matter, even 'The Battle Hymn of the Republic'? ... It's beyond dispute that much of the art that should be taught in schools originates with one great religious tradition or another. . . ."); Bauchman v. West High Sch., Civ. No. 95-C-506G, 1996 WL 407856, at *10 (D. Utah $M$ ay 30, 1996) (denying Bauchman's motion to amend her Establishment Cause claim that was dismissed in Bauchman v. West High School, 900 F. Supp. 254 (D. U tah 1995)).

45. Goodstein, supra note 35 , at A 1 .

46. Charles Reynolds, Sacred Music: How to A void Cooking Your Holiday Goose, MUSIC EDUCATORS J., Nov. 1984, at 31-33. 
A former choir director, who incorporated sacred choral pieces in her choir's repertoire, explained that at times she received pressure from school administrators to eliminate sacred music from the curriculum even though she never discussed religion or theology. ${ }^{47}$

Not surprisingly, confusion, controversy, and public pressure have led educators and school boards to self-censorship. A school district music coordinator in Palo A Ito has explained: "We have to be very, very careful.... We can play seasonal music, like 'Sleigh Ride,' but only songs that in no way mention God or Jesus." ${ }^{8}$ At least one school board has enacted guidelines that highly restrict the use of sacred choral music. In response to complaints by parents about a December music program, the Los Altos, California school district drafted a policy restricting the public performance of vocal music in holiday programs. ${ }^{49} \mathrm{~A}$ draft of the policy stated: "Under no circumstances may educators assign or recruit students to sing songs or parts of songs that are not neutral among all religious beliefs (including polytheistic, monotheistic, non-theistic or atheistic religious beliefs)." ${ }^{50}$ Less restrictive but vaguely worded guidelines may similarly result in the elimination of sacred music from public school music curricula because of the difficulty in determining boundaries. ${ }^{51}$

This chilling effect is dangerous. The importance of music education, particularly performance-based education, in public schools rests on varied and expansive justifications. A ristotle argued: "Clearly actual participation in performing is going to make a big difference to the quality of the person that will be produced ... . musical education must include actual performing." 52 Echoing this statement, modern theorists have argued that: "Of singular importance is the development of the attitude that partici-

47. See Telephone Interview with Shirley Laman, retired public school director of choral activities in Belmont, Massachusetts (Oct. 11, 1996) ("I wasn't teaching religion. I was teaching music.").

48. John Wildermuth, A Little Discord Over School Music: Wringing the Religion out of Winter Concerts Isn't As Easy As It Sounds, S.F. CHRON., Mar. 10, 1995, at P1.

49. See id.

50. Id.

51. See Albert J. Menendez, The December Wars 89-90 (1993) (citing less restrictive policies, including a 1974 Ithaca, N.Y., policy allowing religious music as part of "secular program" or concert provided it is presented in other than a "religious context").

52. A ristotle, A ristotle On the Purposes of Music, in WEISS \& TARUSKIN, supra note 13 , at 11 . 
pation in actual performance produces a better grasp of the aesthetic import of great music than mere listening or nonparticipation." ${ }^{53}$ Education research also reveals the important social function served by music education, demonstrating that, by providing opportunities to work in group settings, music performance strengthens the student's ability to relate and work with others in pursuit of a common goal. ${ }^{54} \mathrm{M}$ usical knowledge has been found to have intrinsic worth as a language, as a "distinctive way of knowing," ${ }^{55}$ and as an integral part of human civilization. ${ }^{56}$ From a functional standpoint as well, study of the arts, including music, has been shown to enhance students' academic success in other areas, as shown by higher standardized test performance and higher grades in non-arts classes. ${ }^{57}$ Performance training also instills discipline and higher quality expectations; students learn the necessity of striving for perfection through exposure to the principle that, while "a 90 percent correct performance on a math test is an A . . . a 90 percent correct performance on stage is a disaster." 58

A s the MENC has explained, to provide students with a complete music education, it is essential that the curriculum include

53. A braham Schwadron, On Religion, Music, and Education, J. RES. MUSIC EdUC., at 157,165 (1970).

54. See Estelle R. Jorgensen, Justifying M usic Instruction in A merican Public Schools: A Historical Perspective, ARTS EDUC. POL'Y REV., July-A ug. 1995, at 31, 32 ("Commonly undertaken in group settings, [music] affords opportunities for individual students to relate with others in the context of creating, performing, and listening to music. It also constitutes an agent for mental and personal growth.").

55. Id. at 33.

[M usic] constitutes an expression of human experience that is irreplaceable by any other means, it makes a unique contribution to human existence, it constitutes a "language" or a "symbol system" that is distinctively musical and unabashedly non-scientific, and it is known holistically and immediately in ways that primarily implicate the imagination and intuition. To take music out of the school curriculum... would result in impoverishing the curriculum by deleting a distinctive way of knowing and a vital part of human civilization and knowledge.

Id. (referring to works by Philip Phenix, Nelson Goodman, and Howard Gardner).

56. See id.

57. See Scott C. Shuler, Why High School Students Should Study the Arts, MUSIC EdUCATORS J., July 1996, at 22-23 (citing The College Board, 1987 Profile of SAT and A chievement Test Takers, C. EnTRANCE ExAmination BOARD, 1, 1, 3 (1987); The College Board, 1988 Profile of SAT and Achievement Test Takers, C. ENTRANCE EXAMINATION BOARD, 1, 1, 3 (1988); The College Board, 1989 Profile of SAT and Achievement Test Takers, C. EnTRANCE EXAmination BOARD, 1, 1, 3 (1989); Daniel Steinel, Grades of High School Arts Students Compare Favorably with Other Students, 2 MENC SOUNDPOST no. 2, Winter 1986, at 14).

58. Id. at 23 . 
music of "all styles, forms, periods, and cultures." 59 It might well be "impossible to understand the history of Western music without [exposure to choral music, including] Gregorian chant, polyphony, the musical settings of the Mass, and the oratorio literature." 60 D ue to the fact that the Church historically patronized the arts, by employing musicians to compose, play, and sing music for worship services, ${ }^{61}$ sacred choral music comprises a substantial portion of the choral music repertoire. ${ }^{62}$ Because sacred choral music constitutes a substantial portion of music literature, it plays an important role in the history of music and "should and does have an important place in music education." 63 And, as the MENC's most recent position statement on this issue explains, the study and performance of sacred choral music is not only an important, but a necessary part of the curriculum. ${ }^{64}$

59. MENC, Position Statement, Religious Music in the Schools, in MUSIC EdUCATORS J., Nov. 1984, at 28 [hereinafter MENC 1984 Position Statement].

60. A lbert J. Menendez, Christmas in the Schools: Can Conflicts be Avoided, PHI DELTA KAPPAN, Nov. 1994, at 239, 241.

61. For example, the career of J ohann Sebastian Bach was "similar to that of many successful musical functionaries of his time in Lutheran Germany," in that Bach maintained religious employment as organist and music director in several churches, as organist and concertmaster in the chapel of the duke of Weimar, and cantor of the St. Thomas' school. Donald Jay Grout \& Claude V. Palisca, A History OF WESTERn MUSIC 497-98 (4th ed. 1988). In fact, music historians have noted the importance of the Church in the development of Western music by stating that "the Church was 'the chrysalis out of which our Western society emerged." Id. at 35. For example, one "'germ of creative power' in the realm of music was embodied in the Gregorian Chant." Id at 497-98.

62. See Doe v. Duncanville Indep. Sch. Dist., 70 F.3d 402, 407 (5th Cir. 1995) (accepting a music teacher's estimation that $60-75 \%$ of serious choral music is based on sacred themes or text and acknowledging the "dominance of religious music in this field"); Bauchman v. West High Sch., 900 F. Supp. 254, 268 (D. Utah 1995) (noting that choral music "often contains religious sentiment"); see also Menendez, supra note 60 , at 241 ("O ne can argue-as many have-that the 'best' music, from the purely cultural perspective, is religious in nature. Indeed, no one would deny that many anthems, carols, and hymns, from Vivaldi's 'Gloria' to Monteverdi's 'Christmas Vespers,' are musically superior to 'Rudolph the Red-Nosed Reindeer' or 'Frosty the Snowman."); MENC, Position Statement, Religious Music in the Schools, MusIC EdUCATORS J., Nov. 1996, insert, at 2 [hereinafter MENC 1996 Position Statement] ("The chorales of J.S. Bach, the "H allelujah Chorus' from George Frideric Handel's Messiah, spirituals, and Ernest Bloch's Sacred Service all have an important place in the development of a student's musical understanding and knowledge.").

63. MENC 1984 Position Statement, supra note 59 , at 29

64. For more than a decade, the MENC has repeatedly issued position statements endorsing the use of sacred music in public schools. Its most recent position statement, adopted in November of 1996, asserts: "It is the position of Music Educators National Conference that the study and performance of religious music within an educational con- 
A Ithough music with a sacred text may have originally been intended to be a vehicle for religious worship and divine praise, it also has an independent secular aesthetic identity because of its significance as music. This is not to say that sacred music has lost all religious significance. Certainly, sacred music may continue to be perceived, by some listeners in some contexts, solely as a vehicle for religious worship and divine praise. However, sacred music may also be perceived-at its inception and beyond-as both a vehicle for religious worship and a secular aesthetic entity that in no way depends on the performer's or the listener's endorsement of the textual message. It is because of this duality, because sacred music does have an independent aesthetic identity and significance within Western music history, that such music is an integral component of a comprehensive music education.

Given the prevalence and importance of sacred choral music within Western music literature, allowing sacred choral music to be "chilled" out of the curriculum through misguided Establishment Clause interpretation would reduce the quality of music education in public schools. It has been argued that "[0]nly barbarians" 65 would remove sacred choral music from public schools and that such removal would disadvantage students by depriving them of some of the best music in the genre. ${ }^{66}$ Furthermore, omitting sa-

text is a vital and appropriate part of a comprehensive music education. The omission of sacred music from the school curriculum would result in an incomplete educational experience." MENC 1996 Position Statement, supra note 62, at 2. Earlier position statements were nearly identical:

It is the position of Music Educators National Conference that the study of religious music is a vital and appropriate part of the total music experience in both performance and listening. To omit sacred music from the repertoire or study of music would present an incorrect and incomplete concept of the comprehensive nature of the art.

MENC 1984 Position Statement, supra note 59, at 29.

65. Donna M. Chavez, Christmas at School: The Goal is to Offend No One: Even the Classroom L eaders Don't A gree on What's A ppropriate, CHI. TRIB., Dec. 12, 1993, § 18, at 3 (quoting $M$ artin Marty, Professor of $\mathrm{H}$ istory of A merican Religion at the $U$ niversity of Chicago).

66.

Musically speaking, the body of religious ... music is vastly superior to the secular music... For school choirs, public performance is as important to learning as is what goes on in the classroom. A high school choral group... denied .... Sixteenth Century polyphonic works of Victoria and Palestrina, $B$ ach and $H$ andel choruses, modern opera classics like Gian Carlo Menotti's A mahl and the Night Visitors, and imaginative arrangements of black spirituals is being shortchanged musically. In many centuries the greatest music has been the music of the church .... . 
cred choral music from the curriculum would not only reduce the quality of music education, but would actually present a false music education. Ignoring the prevalence of sacred choral music within the overall repertoire is, in a sense, to "rewrite music history." ${ }^{67}$ As the MENC has explained, omitting sacred music from the curriculum "would result in an incomplete educational experience" 68 and would present "an incorrect and incomplete concept of the comprehensive nature of the art." 69

Given these pedagogical justifications for teaching and performing sacred choral music in public schools, censoring sacred choral music from curricula seems inconsistent with the principles embodied in the First A mendment. The Supreme Court has repeatedly stressed the importance of the classroom as the quintessential "marketplace of ideas" 70 and the importance of exposing our future leaders to "that robust exchange of ideas which discovers truth 'out of a multitude of tongues, [rather] than through any kind of authoritative selection.'" 71 Music curricula contribute to the creation of this educational marketplace of ideas by "expanding the knowledge and experience" of students. ${ }^{72}$ But, in order to achieve this goal of expanding knowledge and experience, music educators must enjoy academic freedom. Educators must be free to present a representative study of all music- of which sacred choral music is an integral part. ${ }^{73}$ Music educators have made a professional judgment that sacred music is a necessary component of a complete and accurate music education. Eliminating sacred choral music devalues and disregards this professional judgment, thwarting the goal of expanding knowledge and thereby diminishing the marketplace of classroom ideas.

M enendez, supra note 60, at 241-42 (quoting Jean Caffey Lyles, onetime editor of Christian Century).

67. Id.

68. MENC 1996 Position Statement, supra note 62 , at 2.

69. MENC 1984 Position Statement, supra note 59, at 29.

70. Keyishian v. Board of Regents, 385 U.S. 589, 603 (1966).

71. Id. (alteration in original) (citations omitted).

72. MENC 1984 Position Statement, supra note 59, at 29.

73. See id. 


\section{Establishment Clause Precedent}

\section{A. E stablishment Clause Tests}

The archetypal interpretation of the Establishment Clause is that it was intended to erect "a wall of separation between church and State." 74 The Court has since reconsidered this concept of complete separation, recognizing that a complete exclusion of religion from all aspects of public life can sometimes conflict with the Constitution's vow to guard religious liberty. ${ }^{75}$ Instead, the Constitution prohibits those practices that create the dangers the First A mendment was designed to prevent-those practices which involve the state in religious exercise. ${ }^{76}$

In attempting to distinguish those practices that create the dangers the First A mendment was designed to prevent from those practices that do not, the Supreme Court has used a variety of approaches. Given the ambiguity in the text of the First A mendment," ${ }^{77}$ and the "myriad, subtle ways in which Establishment Clause values can be eroded," ${ }^{78}$ this variety is not surprising. Indeed, there is no single test that the Court uniformly applies in all Establishment Clause cases. ${ }^{79}$ Rather, as Justice $O^{\prime}$ Connor has explained, different categories of cases may require different approaches. $^{80}$ ted).

74. Everson v. Board of Educ., 330 U.S. 1, 16 (1947) (internal quotation marks omit(1).

75. See Lee v. Weisman, 505 U.S. 577, 598 (1992).

76. See id. (quoting School Dist. v. Schempp, 374 U.S. 203, 308 (1963) (Goldberg, J., concurring)).

77. See Lemon V. Kurtzman, 403 U.S. 602, 612 (1971) (noting that "the language of . . . the First A mendment is at best opaque"); WILLIAM W. VAN ALSTYNE, FIRST A mendment CASES AND MATERIALS 855 (2d ed. 1995) (stating that "[t]he phrasing of this part of the first amendment is somewhat awkward and ambiguous").

Commentator Leo Pfeffer has noted that the Court "not only applies the rules but interprets them, and since the rules basically consist of but sixteen words . . . the authority is practically open-ended." Leo Pfeffer, GOD, CAESAR, AND THE CONSTITUTION 25 (1975). Given this open-ended authority, in interpreting the text the Court seems more to be making the rules than interpreting them. See id. at 30. Pfeffer has acknowledged the difficulty of the Court's position in light of the "cryptic incisiveness" of the text and the "ever-multiplying and changing nature of the confrontations between religion and government which the Court must resolve." Id.

78. County of Allegheny v. ACLU, 492 U.S. 573, 591 (1989) (quoting Lynch v. Donnelly, 465 U.S. 668, 694 (1984) (O'Connor, J., concurring)).

79. See id. ("not susceptible to a single verbal formulation").

80. See Board of Educ. v. Grumet, 512 U.S. 687, 720-21 (1994) (O'Connor, J., concurring in part and concurring in the judgment) [hereinafter K iryas Joel]. 
The Court has used two approaches that are especially appropriate for analyzing the Establishment Clause ramifications of using sacred choral music in the public schools. ${ }^{81}$ The Court's first approach is the three-part test articulated in Lemon v. Kurtman. ${ }^{82}$ Relying on past decisions, ${ }^{83}$ the Court stated that to survive a constitutional challenge, the government action at issue must: 1) have a secular purpose; 2) have a principal or primary effect that neither advances nor inhibits religion; and 3) "not foster an excessive government entanglement with religion." 84 Although it has been strongly criticized by some members of the Court, ${ }^{85}$ the Court recently noted that the Lemon test has never

81. In addition to the two approaches explained in this Note, the Court has used a third approach, the "fusion" analysis articulated in Kiryas Joel, 512 U.S. at 699. In K iryas J oel, the Court held a New Y ork statute creating a special school district for a religious enclave to be unconstitutional. Relying on prior caselaw, the Court primarily considered two factors: 1) whether the statute "brought about a fusion of governmental and religious functions by delegating important, discretionary governmental powers to religious bodies, thus impermissibly entangling government and religion", id. at 696-97 (internal quotation marks and citations omitted); and 2) whether there were "effective means of guaranteeing that the delegated power [would] be used exclusively for secular, neutral, and nonideological purposes." Id. (alteration in original) (internal quotation marks and citations omitted). This test is appropriate for a case such as K iryas J oel where the government targets a particular group and imposes special duties or provides special benefits. See id. at 719-21 (0'Connor, J., concurring in part and concurring in the judgment). This test seems less appropriate for analyzing the use of sacred choral music in public schools, which falls into the category of cases involving government speech on religious topics or use of religious symbolism.

82. 403 U.S. 602 (1971)

83. See id. at $612-13$.

84. Id. (internal quotation marks and citations omitted).

85. In a sportive dissent to Lamb's Chapel $v$. Center Moriches Union Free School District, J ustice Scalia has written:

As to the Court's invocation of the Lemon test: Like some ghoul in a latenight horror movie that repeatedly sits up in its grave and shuffles abroad, after being repeatedly killed and buried, Lemon stalks our Establishment Clause jurisprudence once again, frightening little children and school attorneys..... Its most recent burial, only last Term, was, to be sure, not fully six feet under: Our decision in Lee v. Weisman conspicuously avoided using the supposed "test" but also declined the invitation to repudiate it. Over the years, however, no fewer than five of the currently sitting Justices have, in their own opinions, personally driven pencils through the creature's heart (the author of today's opinion repeatedly)....

508 U.S. 384, 398 (1993) (Scalia, J., concurring) (citation omitted); see also Kiryas Joel, 512 U.S. at 721 ( $O^{\prime}$ Connor, J., concurring in part and concurring in the judgment) ("As the Court's opinion today shows, the slide away from Lemon's unitary approach is well under way."). But see id. at 710 (Blackmun, J., concurring) ("I write separately only to note my disagreement with any suggestion that today's decision signals a departure from the principles described in Lemon ....."). 
been overruled. ${ }^{86}$ Moreover, in a concurring opinion, Justice Blackmun, joined by Justices Stevens and $O^{\prime}$ Connor, noted that "[i]n no case involving religious activities in public schools has the Court failed to apply vigorously the Lemon factors." ${ }^{87}$ Given the fact that $L$ emon has not been overruled and that it has been consistently applied (or at least cited) in public school Establishment Clause cases, the Lemon framework is appropriate for analyzing the Establishment Clause ramifications of using sacred choral music in public schools.

The Court's second approach is the "endorsement" test, first articulated in Justice $\mathrm{O}^{\prime}$ Connor's concurring opinion in L ynch $\mathrm{V}$. Donnelly ${ }^{88}$ and applied by the Court in several later decisions. ${ }^{89}$ The "endorsement" test incorporates the purpose and effect prongs of Lemon, considering "whether the challenged governmental practice either has the purpose or effect of 'endorsing' religion." ${ }^{90}$ Justice $\mathrm{O}$ 'Connor has explained her focus on "endorsement" as follows: "Endorsement sends a message to nonadherants that they are outsiders, not full members of the political community, and an accompanying message to adherents that they are insiders, favored members of the political community." 91 In a subsequent decision, a plurality of the Court elaborated:

Whether the key word is 'endorsement,' 'favoritism,' or 'promotion,' the essential principle remains the same. The Establishment Clause, at the very least, prohibits government from appearing to

86. See Lamb's Chapel, 508 U.S. at 395 (finding a First A mendment free speech violation when school district denied church's request to use school facility for film showing solely because film dealt with subject from religious standpoint and stating that "permitting District property to be used to exhibit the film ... would not have been an establishment of religion under the three-part test articulated in Lemon"); Kiryas Joel, 512 U.S. at 710-11 (Blackmun, J., concurring) (declining to focus on L emon framework but citing the case as setting forth law and relying on decisions that explicitly rested on L emon criteria).

87. Lee v. Weisman, 505 U .S. 577, 603 n.4 (1992) (Blackmun, J., concurring).

88. 465 U.S. 668, 687 (1984) (O'Connor, J., concurring) ("I write separately to suggest a clarification of our Establishment Clause doctrine.").

89. See Capital Square Review and A dvisory Bd. v. Pinette, 115 S. Ct. 2440, 2447 (1995) (plurality opinion) (referring to the "'endorsement test' which appears in our more recent Establishment Clause jurisprudence"); Lamb's Chapel, 508 U.S. at 395; Board of Educ. V. Mergens, 496 U.S. 226, 249-51 (1990) (opinion of O'Connor, J.); County of A llegheny v. A CLU, 492 U.S. 573, 595-602 (1989) (plurality opinion); Wallace v. Jaffree, 472 U.S. 38, 56 (1985).

90. County of Allegheny, 492 U.S. at 592.

91. L ynch, 465 U.S. at 688 (O'Connor, J., concurring). 
take a position on questions of religious belief or from 'making adherence to a religion relevant in any way to a person's standing in the political community. ${ }^{92}$

The "endorsement" test has been particularly relevant in cases involving the governmental display of religious symbols, such as crèches and crosses. $^{93}$ Because sacred choral music may be considered a form of expression involving religious symbolism, ${ }^{94}$ the endorsement inquiry is also appropriate for analyzing the Establishment Clause ramifications of using sacred choral music in public schools. The test evaluates the message that the government's practice communicates, ${ }^{95}$ inquiring what we "may fairly understand to be the purpose" of the government's use of the religious symbol. ${ }^{96}$ A s the word "fairly" indicates, the standard is objective, considering the perceptions of the "reasonable observer." 97 In

92. County of Allegheny, 492 U.S. at 593-94 (quoting Lynch, 465 U.S. at 687 ( 0 'Connor, J., concurring)).

93. See Pinette, 115 S. Ct. at 2447; County of Allegheny, 492 U.S. at 592; L ynch, 465 U.S. at 681 .

94. Insofar as music is a symbol and sacred music has religious origins, sacred music may be viewed as a form of religious symbolism.

95. See Pinette, $115 \mathrm{~S}$. Ct. at 2454-55 ( $\mathrm{O}^{\prime}$ Connor, J., concurring in part and concurring in the judgment) (noting that the standard for the endorsement test is that of the "'reasonable observer [who] evaluates whether a challenged governmental practice conveys a message of endorsement of religion'") (alteration in original) (citing County of Allegheny, 492 U.S. at 630 (O'Connor J., concurring in part and concurring in the judgment)).

96. County of Allegheny, 492 U.S. at 595; see also Pinette, 115 S. Ct. at 2458-59 (Souter, J., concurring in part and concurring in the judgment) ("Effects matter to the Establishment Clause, and one, principal way that we assess them is by asking whether the practice in question creates the appearance of endorsement to the reasonable observer.").

97. County of Allegheny, 492 U.S. at 620 (opinion of Blackmun, J.); see also Pinette, 115 S. Ct. at 2466 n.4 (Stevens, J., dissenting) (noting that in Allegheny five Justices agreed that the appropriate standard is that of the reasonable observer); id. at 2455 ( $O$ 'Connor, J., concurring in part and concurring in the judgment) (analogizing reasonable observer to the "reasonable person" in tort law who is not "'any ordinary individual'" but is "a personification of a community ideal of reasonable behavior, determined by the [collective] social judgment."') (alteration in original) (citing W. KEETON ET AL., PROSSER AND KEETON ON THE LAW OF TORTS 175 (5th ed. 1984)); Lee v. Weisman, 505 U.S. 577, 597 (1992) ("We do not hold that every state action implicating religion is invalid if one or a few citizens find it offensive.").

However, as Capitol Square Review and Advisory Board v. Pinette demonstrates, although there is agreement that the standard is that of the reasonable observer, there is disagreement within the Court as to the quantum of knowledge that should be attributed to the reasonable observer. See id. at 2454-55 (0 'Connor, J., concurring in part and concurring in the judgment). Some members of the Court would attribute to the reasonable observer a collective knowledge of history and context of the community and forum in 
making this inquiry, context-the particular setting of the display-becomes crucial. ${ }^{98}$ For example, a plurality of the Court has explained: "[A ] typical museum setting, though not neutralizing the religious content of a religious painting, negates any message of endorsement of that content. . . . Every government practice must be judged in its unique circumstances to determine whether it [endorses] religion." 99 In summary, the plurality held that, under the "endorsement" test, the government's use of religious symbolism is unconstitutional if it has the effect of endorsing religion, and that the "effect" is dependent on the context. ${ }^{100}$

Comparison of the Lemon and "endorsement" tests reveals that aspects of the tests overlap. Both tests consider the purpose-actual or perceived-and the effect of the government action. ${ }^{101}$ It has been argued that the Lemon test has been rephrased with "endorsement" language and that the "endorsement" test seems essentially to be a restatement of the first and second L emon criteria. ${ }^{102}$ In addition, when analyzing Establishment

which a governmental display appears. See Pinette, 115 S. Ct. at 2455-56 (O'Connor, J., concurring in part and concurring in the judgment). Justice Stevens, however, would not attribute such collective community knowledge to the reasonable observer and would find an Establishment Clause violation "[i]f a reasonable person could perceive a government endorsement of religion from a private display." Id. at 2466 (Stevens, J., dissenting) (emphasis added).

98. See County of Allegheny, 492 U.S. at 595 (plurality opinion).

99. Id. at 595 (quoting Lynch, 465 U.S. at 694 (O'Connor, J., concurring)).

100. Id. at 597.

101. A lthough the L emon test also considers the "entanglement" factor, that factor is not particularly instructive in analyzing the three hypotheticals in this Note involving the use of sacred choral music in public schools. Entanglement has been interpreted as state involvement in the power structure of a religious organization. Sacred choral music in public schools could conceivably raise entanglement issues if, for example, a school music teacher were also the minister of music or organist at a church, and had the school choir perform during church services. However, entanglement is not the crucial factor in most cases involving sacred choral music. Lower court precedent addressing sacred choral music illustrates the limited applicability of the entanglement factor; courts have found entanglement only when they have found the effect of the government practice is a religious exercise. In other words, they have found entanglement insofar as state actors are involved in directing that religious exercise. See infra Section II.C.

102. See L ynch, 465 U.S. at 690 ( $0^{\prime}$ Connor, J., concurring).

The central issue in this case is whether Pawtucket has endorsed Christianity by its display of the creche. To answer that question, we must examine both what Pawtucket intended to communicate in displaying the creche and what message the city's display actually conveyed. The purpose and effect prongs of the L emon test represent these two aspects of the meaning of the city's action.

Id. See also Underkuffler-Freund, supra note 4, at 969 (quoting Wallace V. Jaffree, 472 U.S. 38, 70 (1985) (O'Connor, J., concurring) ("Recently, the first two prongs of [the 
Clause issues, the Court has often combined Lemon factors with "endorsement" language. ${ }^{103}$ In some cases, the Court seems merely to have cited the opinions from which the tests are drawn, but not to have applied the factors. R egardless of the name of the test applied, however, the relevant Supreme Court E stablishment Clause precedent demonstrates an emphasis on both the purpose and effect of the government action at issue.

\section{B. Relevant Applications}

A Ithough there is no direct Supreme Court statement on the use of sacred choral music in public schools, there is related Supreme Court precedent that bears on the issue, as well as directly relevant lower court precedent. In order to predict how the Court would rule on the constitutionality of the use of sacred music in public schools, it is useful then to explore the relevant caselaw.

1. Supreme Court Precedent. In School District of A bington Township v. Schempp, ${ }^{104}$ the Supreme Court found state-directed devotional Bible reading unconstitutional as a state-directed religious exercise. A Ithough the decision predates the articulation of the Lemon and the endorsement tests, it too analyzes both the purpose and effect of the government action at issue. In analyzing the purpose of the state rule requiring daily Bible reading in public schools, the Court rejected the legislature's avowed secular purpose-" promotion of moral values, the contradiction to the materialistic trends of our times, the perpetuation of our

Lemon] test have been reframed in the terms of 'endorsement': the law or practice, to survive scrutiny, must not 'convey a message that religion or a particular religious belief is favored or preferred."')).

103. See Board of Educ. v. Mergens, 496 U.S. at 226, 248-49 (1990) (Equal A ccess A ct's purpose was not to "endorse or disapprove of religion" (quoting Wallace, 472 U.S. at 56)); see also Edwards v. A guillard, 482 U.S. 578, 593 (1987) (rephrasing Lemon's first factor in terms of endorsement); Wallace, 472 U.S. at 56 (same).

This approach has been used by lower courts addressing the Establishment Clause ramifications of sacred choral music in public schools; these courts have conflated the Lemon and "endorsement" tests by rephrasing the first and second Lemon factors and asking instead "whether the challenged government action was intended to endorse or has the effect of endorsing religion." Bauchman v. West High Sch., No. 95-C-506G, 1996 WL 407856, at *3 (D. U tah May 30, 1996) (quoting Robinson V. City of Edmond, 68 F.3d 1226, 1229 (10th Cir. 1995)); see also Doe v. Duncanville Indep. Sch. Dist., 70 F.3d 402, 405, 406-08 (using several approaches including Lemon test, endorsement test, and what court deems "coercive effect" test of Weisman).

104. 374 U.S. 203 (1963). 
institutions and the teaching of literature." 105 The Court implied that, even if the legislature's true purpose was nonreligious, the effect of "readings, without comment, from the Bible" had a pervading religious character that made the government action unconstitutional. ${ }^{106}$ In so holding, the Court weighed heavily the effect or perceived purpose of the activity, emphasizing factors that demonstrated the religious context of the activity, including the rule's granting of specific permission to use an alternative Catholic version of the Bible and specific permission for nonattendance. ${ }^{107}$ The Court found that these factors were not consistent "with the contention that the Bible is here used either as an instrument for nonreligious moral inspiration or as a reference for the teaching of secular subjects." 108

The Court did qualify its holding in Schempp, stating that using the Bible without such a religious context in an objective presentation of the Bible or of religion, as part of a secular program of education, would be constitutional. ${ }^{109}$

[I]t might well be said that one's education is not complete without a study of comparative religion or the history of religion and its relationship to the advancement of civilization. It certainly may be said that the Bible is worthy of study for its literary and historic qualities. Nothing we have said indicates that such study of the Bible or of religion when presented objectively as part of a secular program of education, may not be effected consistently with the First A mendment. ${ }^{110}$

This statement underscores the importance of context in determining whether the state's use of material with religious content-such as the Bible or sacred music-constitutes unconstitutional "religious exercise" or constitutional study. ${ }^{111}$

105. Id. at 223

106. Id. at 224 (emphasis added).

107. See id.

108. Id.

109. See id. at 225; see also Stone v. Graham, 449 U.S. 39, 42 (1980) (striking statute mandating posting of Ten Commandments on school walls and stating, "This is not a case in which the Ten Commandments are integrated into the school curriculum, where the Bible may constitutionally be used in an appropriate study of history, civilization, ethics, comparative religion, or the like." (citing Schempp, 374 U.S. at 225)).

110. Schempp, 374 U.S. at 225. The Schempp Court distinguished studying the Bible as literature or history from the state-directed, devotional Bible reading at issue in the case, holding that the latter devotional use to be a "religious exercise". Id.

111. The Court similarly relied on context in analyzing the "effect" factor in Lamb's 
Similarly, in Stone v. Graham, ${ }^{112}$ the Supreme Court declared unconstitutional a statute that required the posting of a copy of the Ten Commandments on the wall of each public classroom in the state. ${ }^{113}$ The Court again rejected the legislature's avowed secular purpose-demonstrating the connection between the Ten Commandments and the common law. The Court rejected this purpose, despite the fact that a statement making this connection appeared on each display. ${ }^{114}$ In rejecting the asserted purpose, the Court relied on the effect or perceived purpose of the display, which the Court deemed "plainly religious in nature." ${ }^{115}$ The Court stated:

The Ten Commandments are undeniably a sacred text in the Jewish and Christian faiths, and no legislative recitation of a supposed secular purpose can blind us to that fact. . . . Posting of religious texts on the wall serves no such educational function. If the posted copies of the Ten Commandments are to have any effect at all, it will be to induce the schoolchildren to read, meditate upon, perhaps to venerate and obey, the Commandments. . . . it is not a permissible state objective under the Establishment Clause. ${ }^{116}$

In County of Allegheny v. A merican Civil Liberties Union, ${ }^{117}$ the Supreme Court, citing Lemon as well as the "endorsement" test, considered whether two town displays had the effect of endorsing religion. ${ }^{118}$ In doing so, the Court emphasized the importance of context in determining whether the displays had the effect of endorsement. U sing the standard of a reasonable observer, the

\footnotetext{
Chapel v. Center Moriches Union Free School District, 508 U.S. 384, 395 (1993). In Lamb's Chapel, the Court held that permitting public school property to be used, consistent with the Equal Access Act, by a church to show a religious film would not be an establishment of religion. See id. at 395. The Court found several contextual factors, including the time of the film showing-after school hours-and that the showing would be open to the public, that helped the Court to determine that there was "no realistic danger that the community would think that the District was endorsing religion." Id.

112. 449 U.S. 39 (1980).

113. See id. at $42-43$.

114. See id. at 41 (noting the statement required on each display: "The secular application of the Ten Commandments is clearly seen in its adoption as the fundamental legal code of Western Civilization and the Common Law of the U nited States.").

115. Id.

116. Id. at 41-42 (footnotes omitted).

117. 492 U .S. 573 (1989).

118. See id. at 578.
} 
Court carefully analyzed the particular aspects of each physical setting. ${ }^{119}$ The Court found unconstitutional a display of a crèche, located on the Grand Staircase of the county courthouse, which included an angel bearing a banner proclaiming, "Gloria in Excelsis Deo!"120 The Court explained that nothing in the setting detracted from the crèche's religious message. ${ }^{121}$ In contrast, the Court found constitutional a display, outside the City-County Building, of a menorah next to a Christmas tree, accompanied by an explanatory sign saluting liberty. ${ }^{122}$ The explanatory sign, entitled "Salute to Liberty," stated: "D uring this holiday season, the city of Pittsburgh salutes liberty. Let these festive lights remind us that we are the keepers of the flame of liberty and our legacy of freedom." ${ }^{123}$ While the sign was not the only controlling factor in the decision, the presence of the sign was significant for at least one member of the Court: "The mayor's sign further diminishes the possibility that the tree and the menorah will be interpreted as a dual endorsement of Christianity and Judaism. ... . [A ]n 'explanatory plaque' may confirm that in particular contexts the government's association with a religious symbol does not represent the government's sponsorship of religious beliefs." 124

119. See id. at 595,620 .

120. See id. at 580 ("Glory to God in the Highest").

121. See id. at 598-602.

122. Id. at $613-21$.

123. Id. at 582 (quoting J oint Exhibit Volume 41).

124. Id. at 619 (Blackmun, J., concurring). The Court has noted that similar statements by the government can negate the effect of endorsement. See Widmar v. V incent, 454 U.S. 263, 273, 274 n.14 (1981) (providing equal access to university facilities for student groups, including religious student groups, does not have effect of advancing religion especially in light of fact that student handbook explains that university is not to be identified with the aims or policies of any student organization).

Members of the Court have also encouraged the use of explanatory statements to negate any perceptions of endorsement. In Board of Education v. Mergens, 496 U.S. 226 (1990), the Court found that giving equal access to high school student religious groups would not violate the Establishment Clause. See id. at 253 (O'Connor, J., concurring) (joined by Rehnquist, C.J., White and Blackmun, J.J.). The Court explained that a reasonable observer would not perceive the school to be endorsing religion by granting this equal access and added that the school could take steps to ensure that there would be no misperception. See id. at 251. O 'Connor's concurrence stated that the fear

of a mistaken inference of endorsement is largely self-imposed, because the school itself has control over any impressions it gives its students. To the extent that a school makes clear that its recognition of respondents' proposed club is not an endorsement... students will reasonably understand that the school's official recognition of the club evinces neutrality toward, rather than endorsement of, religious speech. 
The Court did not foreclose the possibility that such a display could have the effect of endorsing religion-as it might, for example, if the menorah were lit in conjunction with the recitation of religious blessings-but explained that given the particular context, the display did not have the effect of endorsing religion. ${ }^{125}$

In Engel v. Vitale, ${ }^{126}$ the Court declared state-directed prayer in public schools to be violative of the Establishment Clause, relying on the undeniably "religious nature" of prayer recognized by Thomas Jefferson, theological writers, and the Court. ${ }^{127}$ The Court explained:

There can, of course, be no doubt that New Y ork's program of daily classroom invocation of God's blessings as prescribed in the Regents' prayer is a religious activity. It is a solemn avowal of divine faith and supplication for the blessings of the A Imighty. The nature of such a prayer has always been religious. ${ }^{128}$

In Lee v. Weisman, ${ }^{129}$ the Court held that inviting clerical members to offer nonsectarian prayers as part of school graduation ceremonies was an unconstitutional act under the Establishment Clause. ${ }^{130}$ Members of the Weisman Court also referred to Engel's "always . . . religious" definition of prayer. ${ }^{131}$

The Court found that by tacitly encouraging standing or silence during the rabbi's invocation and benediction, ${ }^{132}$ the state re-

Id. See also Capitol Square Review \& Advisory Bd. v. Pinette, 115 S. Ct. 2440, 2450 (1995) (Scalia, J., concurring) (joined by Rehnquist, C.J., Kennedy and Thomas, J.J.) (finding no endorsement of religion where state permitted the $\mathrm{Ku} \mathrm{K}$ lux $\mathrm{Klan}$, a private party, to display cross on grounds of state capitol, a public forum, and stating, "[i]f [the state] is concerned about misperceptions, nothing prevents it from requiring all private displays in the Square to be identified as such").

125. See County of Allegheny, 492 U.S. at 620-21.

126. 370 U.S. 421 (1962).

127. Id. at 425 ("The religious nature of prayer was recognized by Jefferson and has been concurred in by theological writers [and] the U nited States Supreme Court.") (quoting trial court).

128. Id. at $424-25$.

129. 505 U.S. 577 (1992).

130. See id. at 599 .

131. Id. at 603 (Blackmun, J., concurring).

132. The invocation read:

God of the Free, Hope of the Brave:

For the legacy of A merica where diversity is celebrated and the rights of minorities are protected, we thank $\mathrm{Y}$ ou. May these young men and women grow up to enrich it.

For the liberty of A merica, we thank $Y$ ou. May these new graduates grow up to guard it. 
quired participation in a "religious exercise." 133 Instead of applying a particular test, the Court analogized the facts to the state-directed prayer recitation that was declared unconstitutional in Engel. ${ }^{134}$ The Court emphasized that the state had directed and controlled the content of the prayers, by inviting a rabbi to give a nonsectarian prayer and by providing him with a pamphlet containing guidelines for the composition of public prayers at civic ceremonies, ${ }^{135}$ in finding that the government's involvement with the religious activity was pervasive "to the point of creating a state-sponsored and state-directed religious exercise in a public school." 136

2. Lower Court Decisions. A Ithough the Supreme Court has never addressed the $\mathrm{E}$ stablishment Clause ramifications of teaching and performing sacred choral music in public schools, several lower courts have confronted the issue. ${ }^{137}$ In addressing the issue,

For the political process of A merica in which all its citizens may participate, for its court system where all may seek justice we thank Y ou. May those we honor this morning always turn to it in trust.

For the destiny of A merica we thank $\mathrm{Y}$ ou. $\mathrm{M}$ ay the graduates of $\mathrm{N}$ athan Bishop Middle School so live that they might share it.

May our aspirations for our country and for these young people, who are our hope for the future, be richly fulfilled.

AMEN.

Id. at $581-82$

The benediction read:

O God, we are grateful to $\mathrm{Y}$ ou for having endowed us with the capacity for learning which we have celebrated on this joyous commencement.

$\mathrm{H}$ appy families give thanks for seeing their children achieve an important milestone. Send Y our blessings upon the teachers and administrators who helped prepare them.

The graduates now need strength and guidance for the future, help them to understand that we are not complete with academic knowledge alone. We must each strive to fulfill what $Y$ ou require of us all: To do justly, to love mercy, to walk humbly.

We give thanks to Y ou, Lord, for keeping us alive, sustaining us and allowing us to reach this special, happy occasion.

AMEN.

Id. at 582 .

133. Id. at 593, 599 (stating that a student who stood or remained silent during the prayer could believe that the group exercise "signified her own participation or approval of it," rather than "mere respect" of it). A Ithough objecting students did have the choice of protesting, the Court found that this choice was not acceptable given the susceptibility of adolescents to conform due to peer pressure. See id. at 593-94.

134. See id. at 596-97 (citing Engel v. Vitale, 370 U.S. 421, 430 (1962)).

135. See id.

136. Id. at 587 .

137. See infra notes $\mathbf{1 3 8}-90$ and accompanying text; see also Sease v. School Dist., 811 
lower courts have used a variety of approaches, including the purpose, effect, and entanglement factors of L emon test, as well as the purpose and effect factors of the Lemon test rephrased in terms of endorsement.

In D oe v. A ldine Independent School District, ${ }^{138}$ a Texas federal district court, applying L emon, found state-directed recitation and singing of a school prayer violative of the Establishment Clause. ${ }^{139}$ The prayer ${ }^{140}$ was posted on the gymnasium wall and either recited or sung at various school activities at the initiation of the principal or other school employees. ${ }^{141}$ The court held that the words met the Engel Court's definition of "prayer," because the words invoked divine blessing and contained an avowal of divine faith. ${ }^{142}$ In so holding, the court found no constitutional distinction between the singing or recitation of the prayer and referred alternatively to the prayer as a "school prayer" and as a "school song." 143 In analyzing the Lemon purpose factor, the court found that the stated purpose- to instill school spirit and pride which increases morale and lessens disciplinary problems-could be achieved through nonreligious means. ${ }^{144}$ A s such, the court determined that reciting and singing the prayer did not have a secular purpose. ${ }^{145}$ The court also determined that the practice advanced religion because the state-directed recitation or singing of the prayer at pep rallies, football games, and graduation ceremonies indicated that the state advocated religious belief. ${ }^{146}$ A Iso, because school employees directed the practice on school property, the court found that the recitation and singing of the prayer involved excessive entanglement with religion. ${ }^{147}$

\footnotetext{
F. Supp. 183 (E.D. Pa. 1993) (finding non-curriculum gospel choir in violation of Equal $A$ ccess $A$ ct by engaging in school-sponsored religious activities).

138. 563 F. Supp. 883 (S.D. Tex. 1982)

139. See id.

140. The text of the prayer was: "Dear God, please bless our school and all it stands for. Help keep us free from sin, honest and true, courage and faith to make our school the victor. In Jesus' name we pray, A men." Id. at 884 (internal quotation marks omitted).

141. See id. at 885 .

142. See id.

143. Id. at 885-86.

144. See id. at 886 .

145. See id.

146. See id. at 887 .

147. See id. at 887-88.
} 
In Florey v. Sioux Falls School District, ${ }^{148}$ the Eighth Circuit supported the constitutionality of singing Christmas carols in public schools by upholding school district rules that permitted the objective presentation of sacred music for school-sponsored activities and programs and the objective study of sacred music within the curriculum as constitutional. ${ }^{149}$ A pplying the three factors of the L emon test, and relying on Schempp's statement that the objective study of religion as part of a secular program of education is permissible, the Court found the rules constitutional. ${ }^{150}$ In finding the purpose of the rules- to teach the role of religion in the social, cultural, and historical development of civilization-to be a legitimate, secular purpose, the court distinguished the purpose of the state-directed prayer in Engel and the state-directed Bible reading in Schempp. ${ }^{151}$ In determining that the effect of the rules did not advance or inhibit religion, the court specifically found that the term "study" included more than classroom instruction and encompassed public performance. ${ }^{152}$ As such, the court found that the singing of Christmas carols in accordance with the school department rules would have a primarily secular effect. ${ }^{153}$ The court also relied on the cultural significance of Christmas carols in determining that the effect of singing the carols would be primarily secular. ${ }^{154}$ Finally, in addressing the third L emon factor, the Court found that rather than fostering an excessive state entanglement of religion, the school department rules provided means to ensure that schools would not engage in "religious exercises." 155

More recently, in Doe v. Duncanville Independent School District, ${ }^{156}$ the Fifth Circuit found a public school choir's designation of John Rutter's The L ord Bless You and Keep You as the choir's theme song to be constitutional. ${ }^{157}$ The song was recognized by students as the theme song but was not demarcated as

\footnotetext{
148. 619 F.2d 1311 (8th Cir. 1980).

149. See id.

150. See id. at 1313-18.

151. See id. at 1314-15.

152. See id. at 1316.

153. See id. at 1315-18, 1319.

154. See id. at 1315-18.

155. Id. at 1318.

156. 70 F.3d 402 (5th Cir. 1995).

157. See id. at $401-08$.
} 
such in the one concert program in the record. ${ }^{158}$ The choir sang the theme song at the end of performances, at the end of class on Fridays, during choral competitions, and on bus rides home from performances. ${ }^{159}$ The parties acknowledged the constitutional permissibility, under Schempp, of singing sacred choral music as part of a secular music program. ${ }^{160}$ However, there was a dispute as to whether treating the song as theme song, rather than merely one in the repertoire, transforms the permissible practice into an "endorsement" of religion. ${ }^{161}$

Citing the Lemon test, the endorsement test, and $L$ ee $v$. Weisman, the Fifth Circuit analyzed the case using a combined Lemon/endorsement approach, considering whether there was a secular purpose to the practice and whether the practice effectively endorsed religion. ${ }^{162}$ Citing the choir director's opinion that The Lord Bless You and Keep You is useful in teaching students to sight-read and to sing without instrumental accompaniment, the court stated that there was a legitimate secular purpose in maintaining the song as theme song. ${ }^{163}$ The court found that labelling The Lord Bless You and Keep You as theme song did not effectively endorse religion because of the predominance of sacred music within the repertoire of choral music. ${ }^{164}$ The court also stated that singing the theme song was not a religious exercise and distinguished Aldine on the basis that Aldine involved a schoolcomposed prayer sung before athletic events rather than the widely recognized choral music at issue in Duncanville. ${ }^{165}$ The court rejected the relevance of the fact that students would identify their choir by the theme song because of the crucial point that in the world of choral music, "singing about religion is not the same as endorsing or exercising religion." ${ }^{166}$ Since singing the theme song was not a "religious exercise," the court determined there was no excessive entanglement with religion. ${ }^{167}$

\footnotetext{
158. See id. at 407 n.6.

159. See id. at 404 .

160. See id. at 407.

161. See id.

162. See id. at 405-08.

163. See id. at 407.

164. See id. at 407-08.

165. See id. at 407 n.7.

166. See id. at 407-08 nn.7-8.

167. See id. at 408 n.7.
} 
In Bauchman v. West High School, ${ }^{168}$ a U tah federal district court dismissed an Establishment Clause claim involving a public school choir's performance of sacred choral music by contemporary Christian songwriters, including R utter's The L ord B less $Y$ ou and $\mathrm{K}$ eep $\mathrm{You}$, in several churches, for failure to state facts supporting a constitutional violation. ${ }^{169}$ The court distinguished $L$ ee $v$. Weisman and applied the Lemon factors. ${ }^{170}$ The court distinguished Weisman on the basis that singing sacred music is not a "religious exercise" and that sacred music is not the equivalent of prayer. ${ }^{171}$

The Bauchman court then applied the three factors of the L emon test. ${ }^{172}$ First, the court found that the choir director's selection of contemporary Christian music and religious performance sites had a primarily secular purpose-that of teaching broad musical appreciation and increasing awareness of culture and diversity. ${ }^{173}$ The plaintiff argued that, while performing sacred choral music of a particular quality might be constitutionally permissible because of its significance within the Western music tradition and culture, performance of low quality sacred music, such as the contemporary music at issue in the case, would not be constitutionally permissible. ${ }^{174}$ This lack of musical quality, the plaintiff argued, demonstrated a religious motive in the selection of the music. ${ }^{175}$ The court rejected this argument, finding that it would be impracticable for courts to evaluate the constitutionality of sacred choral music on the basis of high or low musical quality. ${ }^{176}$ Second, the court determined that the primary effect was not the advancement or inhibition of religion, but rather, the teaching of musical skills and appreciation. ${ }^{177}$ Third, the court found that there was no excessive entanglement by the state with religion given the fact that any selection of choral music will entail involvement with religion

168. 900 F. Supp. 254 (D. U tah 1995).

169. See id.

170. See id. at 267-69.

171. See id. at 268.

172. See id. at 268-69.

173. See id. at 269 .

174. See id. at 268 n.18.

175. See id.

176. See id.

177. See id. at 269. 
due to the pervasive role of sacred music within the repertoire of choral music. ${ }^{178}$

A fter the case was dismissed, the plaintiff moved to amend her claim; this motion was also dismissed. ${ }^{179}$ In considering the allegations in the plaintiff's motion, the court applied the first two factors of the L emon test, rephrased with endorsement language, considering whether, under the standard of a reasonable observer, there was a purpose to endorse or the effect of endorsing religion. ${ }^{180}$ The court found no purpose to endorse religion despite the choir director's selection of contemporary Christian music and his statements, such as "I don't believe in leaving my religion at home" 181 and "I'm just a religious man. It's just a part of my life that I can't ignore." 182 In addition, the court again rejected the argument that the low musical quality of the selections demonstrated a purpose to endorse religion, declining to conduct an aesthetic analysis of the sacred music selected by the choir director. ${ }^{183}$

The court similarly found no endorsement of religion. ${ }^{184}$ The court rejected the argument that the choir director's teaching style had the effect of endorsing religion, despite the fact that in rehearsal he instructed the class to "feel the music, listen to the words, don't just sing it without thinking about the words." 185 The court noted that the choir director never told the choir to believe the lyrics or to believe the message of the lyrics, that he never talked to the choir about religion, and that he never told the choir he was a Mormon nor encouraged students to become Mormons or Christians. ${ }^{186}$ The court found that the choir director's comments at the year's final concert, presented in a church, thanking his "'heavenly father' for 'the opportunity in working with these young people'" did not have the effect of endorsing religion. ${ }^{187}$ In so finding, the court relied on the affida-

\footnotetext{
178. See id.

179. See Bauchman v. West High Sch., Civ. No. 95-C-506G, 1996 WL 407856 (D. U tah May 30, 1996).

180. See id. at $* 3-* 9$.

181. Id. at $* 4$.

182. Id. at $* 9$.

183. See id. at $* 6 \mathrm{nn} .43-44$.

184. See id. at $* 9$.

185. Id. at $* 7$.

186. See id. at $* 7-* 8$.

187. Id. at $* 8$.
} 
vit of a student who perceived the statements not as a prayer but as "an emotional speech ... a the end of the school year" and "his own personal statement." ${ }^{188}$ The court also rejected the argument that the performance of sacred choral music and Christmas carols in December had the effect of endorsing religion, emphasizing that these performances were not in conjunction with religious services. ${ }^{189}$ In addition, the court stated that the choir's performances in churches or other religious sites did not have the effect of endorsing religion, again emphasizing that such performances were concerts and not in conjunction with religious services. ${ }^{190}$

\section{Framework for A nalyzing Sacred Choral Music in Public Schools}

W ith this Establishment Clause precedent in mind, this Note analyzes sacred choral music issues using a combined Lemon/endorsement approach, rephrasing the first two L emon factors, purpose and effect, in endorsement terms. This analysis asks two questions: First, is there a purpose to endorse religion? A nd second, is there an effective (i.e., reasonably perceived) endorsement of religion? Despite the apparent coequal status of these two factors, this Note seeks to demonstrate that in analyzing the use of sacred music in public schools, the question of purpose is of little utility, and that the controlling inquiry is instead that of "perceived purpose" or "effect". And in considering the effect, the proper inquiry, as the Court explained in County of Allegheny and L ynch, is "what viewers may fairly understand to be the purpose" of the state's use of religious symbolism; this inquiry will depend upon context. ${ }^{191}$ Because the extant Establishment Clause tests have proved malleable and seem capable of yielding inconsistent results, ${ }^{192}$ this Note will not utilize a mechanical application of

188. Id.

189. See id. at $* 5$.

190. See id. at $* 4$.

191. County of Allegheny v. ACLU, 492 U.S. 573, 595 (1989) (citing Lynch v. Donnelly, 465 U.S. 668, 692 (1984)).

192. See Marsh v. Chambers, 463 U.S. 783, 795 (1983) (upholding state legislative practice of beginning each session with prayer by a chaplain chosen biennially by the Executive Board of the Legislative Council and paid out of public funds). But see Kiryas Joel, 512 U.S. 687, 720 (1994) (O'Connor, J., concurring) ("[c]ourts tend to continually try to patch up the broad test, making it more and more amorphous and distorted. This, 
factors. Rather, this Note will focus on relevant analogous and distinguishable facts of relevant Supreme Court Establishment Clause cases in analyzing the constitutionality of teaching and performing sacred choral music in three hypothetical public school contexts. ${ }^{193}$

\section{Analyzing the Establishment Clause Ramifications of SaCRED ChORAL MUSIC IN PUBLIC SChOOLS IN SPECIFIC CONTEXTS}

\section{A. Teaching and Performance}

A high school choral director selects excerpts from $\mathrm{H}$ andel's Messiah ${ }^{194}$ for the December chorus concert. Her primary motivation in selecting the work is because of its historical significance and because it will expose the students to collaboration with orchestra. She discusses this historical significance with the choir and explains that it is because of this significance that she has selected the piece. However, the teacher is Christian and, as such, she hopes in her inner heart of hearts that, after exposure to $\mathrm{H}$ andel's Messiah, students will be so moved by the music that they will embrace the underlying message of the text and become Christians. During the course of rehearsal, she encourages students to "feel the music." She never discusses religion; she does not pray and she does not explicitly or implicitly encourage students to join a particular faith. For the concert, she writes program notes that articulate the historical background and musical significance of the piece. Is this use of sacred choral music constitutional?

\footnotetext{
I am afraid, has happened with Lemon."); Lamb's Chapel v. Center Moriches Union Free Sch. Dist., 508 U.S. at 384, 399 (1993) (Scalia, J., concurring) ("The secret of the Lemon test's survival, I think, is that it is so easy to kill. It is there to scare us (and our audience) when we wish it to do so, but we can command it to return to the tomb at will. When we wish to strike down a practice it forbids, we invoke it, when we wish to uphold a practice it forbids, we ignore it entirely. Sometimes, we take a middle course, calling its three prongs 'no more than helpful signposts.' ... For my part, I agree with the long list of constitutional scholars who have criticized Lemon and bemoaned the strange Establishment Clause geometry of crooked lines and wavering shapes its intermittent use has produced." (citations omitted)); Lee v. Weisman, 505 U.S. 577, 586-99 (1992) (holding unconstitutional the practice of allowing school-selected member of clergy to present prayer at high school graduation ceremony).

193. See Kiryas Joel, 512 U.S. at 719 (O'Connor, J., concurring) ("[I]t is more useful to recognize the relevant concerns in each case on their own terms.").

194. George F. Handel, MESSIAH (Watkins Shaw ed., 1981).
} 
In applying the "purpose" factor of the Lemon-endorsement inquiry, a court would consider the choral director's subjective purpose in using $\mathrm{H}$ andel's Messiah. In Lemon language, a "legitimate secular purpose"-educating students about a musically significant work and developing the collaborative skill of working with orchestra-is present. Lower courts, commentators, and music educators have all noted that sacred choral music comprises a majority of the choral literature in existence; in fact, many have argued that such music is some of the best in the literature. ${ }^{195}$

In this hypothetical example, however, the teacher has mixed motives-secular and religious-for selecting Handel's M essiah. $G$ iven that a legitimate secular purpose may fairly be understood, of what legal relevance, if any, is the teacher's inner, and unvoiced, religious motive? In several cases, the Supreme Court has indicated that the subjective intentions of state actors are relevant to Establishment Clause analysis. The Court has consistently attempted to separate the religious and secular "motivations" of state actors. ${ }^{196}$ In Edwards, for instance, the Court rejected the secular purpose avowed by the state because it deemed the actual and perceived purposes of legislators to be religious: "While the Court is normally deferential to a State's articulation of a secular purpose, it is required that the statement of such purpose be sincere and not a sham." 197 The Court seems to have discounted the importance of the articulated nonreligious purpose, because it determined that the perceived purpose-or effect-was in fact religious.

A Ithough consideration of legislative purpose might be appropriate in some cases, the use of subjective purpose as a determinative factor in the context of using sacred music in public schools is problematic. First, the task of distilling a pure secular or religious motivation is impossible. ${ }^{198}$ As one commentator has argued, "The purity of separation of religious and secular motivations within individuals is simply an actual and analytical impossibility." 199 Second, consideration of the teacher's unvoiced motive

195. See supra note 62 .

196. See U nderkuffler-Freund, supra note 4 , at 859.

197. Edwards v. A guillard, 482 U.S. 578, 586-87; see also supra text accompanying notes 105-16.

198. See U nderkuffler-Freund, supra note 4, at 865 n.109 (noting J ustice Scalia's comments regarding the multiplicity of legislative motivations).

199. Id. 
would produce absurd or inconsistent results. It would be absurd to hold that the performance of an entirely secular music program would be unconstitutional because the instructor harbored religious motivations or aspirations in its selection. If the music were sacred in nature, the use of purpose as a determinative factor would create other difficulties. A ssuming an identical set of facts, it does not make sense that the same teaching and performance context would be constitutional absent religious motivation but unconstitutional if an unvoiced religious motivation were present.

Perhaps based on these reasons, the court in Bauchman seems to have discounted the "purpose" factor. ${ }^{200}$ In applying the purpose factor of a rephrased Lemon/endorsement test, the court found no violation of the $\mathrm{E}$ stablishment Clause, although the music teacher who used sacred music acknowledged, "I have a little trouble with this separationist concept" and "I don't believe in leaving my religion at home." ${ }^{201}$ With these statements, the court could not have truly weighed the "purpose" factor and still found no violation of the Establishment Clause. What should be-and what seems to be-more determinative of constitutionality is not the state's actual purpose but the "perceived" purpose-or the effect- of using the music. ${ }^{202}$

The crucial inquiry carefully considers how the music teacher uses the music, by analyzing the context of the use. That the context of the teaching and performing of sacred choral music is crucial is evident in the language of those cases where the Court has rejected an avowed secular purpose. ${ }^{203}$ Although the Court considered purpose in those cases, the Court concentrated on the

200. See Bauchman v. West High Sch., Civ. No. 95-C-506G, 1996 WL 407856, at *4, *9 (D. U tah May 30, 1996).

201. Id.

202. This view finds support in Justice Stevens' dissenting opinion in Mergens. Justice Stevens explained that in analyzing L emon's purpose prong, the crucial inquiry is whether the government action at issue "reflects a judgment that it would be desirable for people to be religious or to adhere to a particular religion. The plurality is correct to observe that it is irrelevant whether the legislature itself behaved religiously when it made (or abstained from making) that judgment." Board of Educ. v. Mergens, 496 U.S. 226, 286 n.21 (1990) (Stevens, J., dissenting). A s the language "reflects a judgment" indicates, the effect is determinative. The relevant aspect of the purpose inquiry-the perceived purpose-whether the government action reflects a judgment that it is desirable to be religious, is subsumed in the effect analysis, which considers the message the government practice communicates.

203. See Stone v. Graham, 449 U.S. 39, 42 (1980); School Dist. v. Schempp, 374 U.S. 203, 224 (1963). 
context of accompanying state legislation or state action. ${ }^{204}$ It follows that, in considering the constitutionality of teaching and performing sacred choral music in public schools, it is the "effect" or "perceived purpose" factor, analyzed in terms of context, that is most probative. ${ }^{205}$

Thus, in applying the "effect" factor, consideration of whether the use of Messiah in this hypothetical has the effect of endorsing religion requires analysis of the context of the choral director's use. In this hypothetical, the context of the rehearsal and performance do not have the effect of endorsing religion. There are several factors that might contribute to the context of a performance, and that indicate that this hypothetical performance does not have the effect of endorsing religion. These include the site and time of year of the concert, the placement of particular selections within the order of the program, the presence of program notes explaining the musical significance of works performed, and the nature of performative artifice.

A s the Supreme Court has noted, a "typical museum setting, though not neutralizing the religious content of a religious painting, negates any message of endorsement of that content." 206 Similarly, even if a piece of sacred choral music was originally composed for use in a worship service, ${ }^{207}$ the use of that music

204. See supra text accompanying notes 104-16 (discussing Schempp, 374 U.S. at 224 (striking state-directed Bible reading and holding that use of Bible at issue was not for nonreligious moral inspiration or as reference for teaching of secular subjects); Stone, 449 U.S. at 42 (striking mandatory posting of Ten Commandments on school walls and stating, "[t]his is not a case in which the Ten Commandments are integrated into the school curriculum, where the Bible may constitutionally be used in an appropriate study of history."); County of A llegheny v. A CLU, 492 U.S. 573, 619 (1989) (finding display of menorah and Christmas tree constitutional in part because of presence of explanatory sign saluting liberty)); see also Steven B. Epstein, Rethinking the Constitutionality of Ceremonial Deism, 96 Colum. L. Rev. 2083, 2132 (1996) ("Most of the laws and practices the Supreme Court has found to violate the Establishment Clause have been invalidated under Lemon's or the endorsement test's effect prong.") (citing Engel v. Vitale, 370 U.S. 421 (1962); Schempp, 374 U.S. at 203; County of Allegheny, 492 U.S. at 573; Lee V. Weisman, 505 U.S. 577 (1992)).

205. See supra notes $106-25$ and accompanying text (discussing Court's language emphasizing context).

206. County of Allegheny, 492 U.S. at 595 (quoting Lynch v. Donnelly, 465 U.S. 668, 692 (1984) (O'Connor, J., concurring)).

207. Handel's Messiah is not such a piece; it was originally intended for concert hall performance and was so performed during Handel's life. See LEONARD VAN CAMP, A Practical Guide for Performing, Teaching and Singing Messiah 4 (1993) (noting that during $\mathrm{H}$ andel's life Messiah was performed " 36 times, always in March, A pril, or May and never in a church."). 
in a true performative context, and outside the worship service, negates any message of endorsement. The very nature of the word-performance-connotes theatrical artifice. Theatrical performance, including this hypothetical concert, involves "training, rehearsal, and planning on the part of its producers," 208 and, on the part of its audience, requires "a sustained imaginative collusion with the events portrayed by the actors." 209 The key word here is imagination: the reasonable audience member can be expected to use their imagination to engage in the performance, rather than impute to the performer belief or endorsement of the message of every piece performed in a concert. $\mathrm{H}$ istorically, theatrical performance has been criticized for its disclaimer of reality; such performance is said to be based on "hypocrisy," where the performers feign and fictionalize, attempting "to substitute "notorious lying fables,' . . . for things that have truly happened." ${ }^{210}$ Lower courts have emphasized this notion of performative artifice in finding that performances of sacred music in public schools do not necessarily endorse religion. ${ }^{211}$

Evaluation of effect thus necessarily involves consideration of the reasonable expectation of the audience. Individuals attend worship services with the desire and expectation of participating in a religious exercise; they attend with the desire and expectation of listening, endorsing, and being moved by the religious message that is set forth in word and song. In contrast, individuals attend a concert, not with the expectation of participating in a religious exercise or endorsing a religious message, but with the desire and expectation of listening to music. The expectations of audience members at a concert are thus similar to the expectations of the

208. Jonas Barish, The Anti-Theatrical Prejudice 81 (1981).

209. Id.

210. Id; see also Steven B. Katz, The Epistemic Music of Rhetoric 213 (1996) (quoting Susanne Langer, Feeling and Form: A Theory of ARt 139-40 (1953), in distinguishing "artistic utterance" which "'always strives to create as complete and transparent a symbol as possible" from "personal utterance" which arises from "actual emotion [and] usually contents itself with half-articulated symbols'").

211. See Bauchman v. West High Sch., Civ. No. 95-C-506G, 1996 WL 407856, at *4 (D. Utah May 30, 1996) ("The five off campus performances which were held at sites owned by religious institutions were concerts not in conjunction with religious services."); Doe v. Duncanville Indep. Sch. Dist., 70 F.3d 402, 407-08 \& n.8 (5th Cir. 1995) ("[P]articularly in the world of choral music, singing about religion is not the same as endorsing or exercising religion."). 
viewers of art in a "typical museum setting," a context which "negates any message of endorsement." 212

Theories regarding the aesthetics of music ${ }^{213}$ further illustrate the relevance of listener expectation and perception in a legal analysis of context. Under a holistic view of music, a musical work is created not just by acts of composition (the composer writing the music), but also by acts of interpretation (the interpretive choices the artist makes in performing the work) and acts of perception (how the listener perceives the performance of the work). Insofar as expectation influences perception, if listener expectation and perception are musically relevant factors in creating the musical work, certainly listener expectation and perception are also relevant in considering the legal effects of performing that musical work.

True, the text of the Messiah's "Glory to God" ${ }^{214}$ is identical to the text of the state-sponsored crèche display that was declared unconstitutional in County of Allegheny. ${ }^{215}$ However, although the texts are nearly identical, there are important distinctions. First, as noted above, a performance in a concert setting makes no claim of reality; the performance is art, which by its nature is, at most, an alterer and imitator of reality, but not in fact reality. ${ }^{216}$ The text in County of Allegheny, given its placement above a Christmas crèche display in a county courthouse, was unconstitutional in its similarity to the words being uttered in a church service. ${ }^{217}$ There was "nothing in the context of the display [to] detract[] from the crèche's religious message." ${ }^{218}$ That is, there was no disclaimer of reality; there was no claim of "performance" - no claim that the state, by presenting the crèche and accompanying message in the county courthouse, was not endorsing the religious

\footnotetext{
212. County of Allegheny v. ACLU, 492 U.S. 573, 595 (1989) (quoting Lynch v. Donnelly, 465 U.S. 668, 692 (1984) (O'Connor, J., concurring)).

213. See supra note 29 .

214. The text reads, "Glory to God in the highest, and peace on earth, goodwill toward men." George F. Handel, Glory to God from MESSIAH 68 (Watkins Shaw ed., 1981).

215. See supra notes $117-21$ and accompanying text.

216. See George R. Puttenham, The Arte of English Poesie, in 2 Elizabethan CRITICAL ESSAYS 1, 188 (G. Gregory Smith ed., 1904) ("[A ]rte is . . a an alterer [of nature] ... arte is ... a bare immitatour of natures works, following and counterfeyting her actions and effects.....").

217. See County of A llegheny 492 U.S. at 598.

218. Id. at 573 .
} 
content of the message. The reasonable perception of the audience in the County of Allegheny context was that this display was a realistic symbol of the state's religious preferences. In the context of the above hypothetical, however, the reasonable perception of an audience would be that the performance is just that-a performance-and not a statement of religious ideology. The performance context detracts from the significance of the music as a religious symbol and emphasizes the significance of the music as art.

This is not to say that all "performances" of sacred music will negate any effect of endorsement and will be constitutional. A Ithough the notion of performance and the artifice encompassed therein will weigh heavily in terms of negating any inference of endorsement, there might be other contextual elements that could cause a performance to convey a message of endorsement. Certainly, if the high school chorus were to perform Messiah as part of a worship service, there could be an effect of endorsement. Even if the students involved felt that they were merely entertaining, a reasonable observer might fairly perceive them to be participating in a religious exercise. Remarks by the conductor might also cause a performance to convey a message of endorsement. For example, opening a concert with a prayer recitation ${ }^{219}$ or delivering a speech that thanks God for having the opportunity to make music would tend to lessen the performative aspect of the concert and emphasize the religious nature of the music. One might argue then, that the choir director's comments in Bauch$\operatorname{man}^{220}$ did have the effect of endorsing religion. By invoking divine thanks in his "real" as opposed to performative statements, in a concert presented in a religious site, the choir director's statements could result in the fair inference that the accompanying performance of sacred music was a musical extension of his personal beliefs and an endorsement of religion. In finding that an objective, reasonable observer would not view the choir director's statements as endorsing a particular religion, the Bauchman court may have relied too heavily on the fact that particular observers

219. Cf. Sease v. School Dist., 811 F. Supp. 183, 189-90 (E.D. Pa. 1993) (relying in part on pre-performance prayer sessions in concluding that a high school gospel choir's activities were religious in nature for $E$ qual $A$ ccess $A$ ct purposes).

220. See supra notes $181-82$ and accompanying text. 
did not perceive his statements to be a prayer or to be an endorsement of religion. ${ }^{221}$

The site of the performance also contributes to context. A Ithough a performance in a concert hall is less likely to convey a message of endorsement, it may be possible to have a concert in a religious site-such as a church or temple-without conveying an endorsement of religion. The key factors in the analysis of a performance at a religious site would be the presence of performative accoutrements which might include applause, distributing a program with explanatory notes, labelling the event a concert, and opening the concert to the public. A nother factor that contributes to the context of this hypothetical is the time of year. The fact that the concert is in December, however, does not cause the performance to convey a message of endorsement. The Court has repeatedly held that Christmas has become a part of A merican secular culture. ${ }^{222}$ This secularization of Christmas weighed in the Eighth Circuit's determination, in Florey v. Sioux Falls School District, ${ }^{223}$ that the singing of Christmas carols in public schools did not have the effect of endorsing religion. ${ }^{224}$ Moreover, the particular use of $\mathrm{H}$ andel's Messiah in a December concert has greater secular than religious significance. First, the piece was originally composed for the concert hall, not for the Church. ${ }^{225}$ Second, the use of the Messiah during the Christmas season is an A merican cultural phenomenon that originated with secular music organizations, ${ }^{226}$ the piece was originally performed in A pril. ${ }^{227}$

221. See Bauchman v. West High Sch., Civ. No. 95-C-506G, 1996 WL 407856, at *8 (D. Utah May 30, 1998).

222. See, e.g., County of Allegheny, 492 U.S. at 601 (noting that "government may celebrate Christmas in some manner and form, but not in a way that endorses Christian doctrine").

223. 619 F.2d 1311 (8th Cir. 1980).

224. See supra notes $148-55$ and accompanying text

225. See VAN CAMP, supra note 207, at 3-4 (debunking the myth that Messiah was a Christmas piece intended as church music, and noting that it was first performed in a secular hall and "was not written as church music"). "Handel was never a church musician, and he seldom wrote music for the Church. He was always a composer for the theatre and the concert hall .... In his day Messiah was a public 'entertainment' .....' Id. at 4 (quoting ROBERT MANSON MYERS, A TOUChSTONe OF TASTE 84-85 (1971)).

226. See id. at 4 (noting that the annual Christmas performance tradition originated in B ritain with the Caecilian Society of London and in the United States with The Boston $\mathrm{H}$ andel and $\mathrm{H}$ aydn Society and that the "annual Christmas Messiahs ... ha[ve] become an A merican phenomenon").

227. See id. at 3 (noting that the piece was first performed on A pril 13, 1742). 
Perhaps even more important than this cultural secularization in negating any effect of endorsement is the presence of program notes in the above hypothetical. Program notes describe the relevant musical characteristics of a piece and explain the significance of a piece of music within the genre. Thus, program notes are analogous to the sign in County of Allegheny, which held that the menorah and Christmas tree in the town's display did not effectively endorse religion. While the explanatory sign was not the only factor in the decision, Justice Blackmun found the sign's presence significant in negating any message of endorsement. ${ }^{228}$

The presence of program notes in this hypothetical serves a similar purpose to the sign in County of Allegheny, and, while the presence of program notes is not the only controlling factor, it is similarly significant. Music never exists in a vacuum; it is always the product of a variety of forces-historical, political, literary, or religious-affecting the composer. Program notes can educate audiences as to those forces. By educating audiences as to the musical reasons for the performance and by focusing audience attention on musically relevant aspects of the work, program notes reinforce the identity of the music as an independent aesthetic entity rather than as a vehicle for promoting a religious message. ${ }^{229}$ A ccordingly, even a performance of sacred choral music where students participated in a processional march or carried candles could be constitutional if the musical explanation for a processional march or incorporating candles were carefully conveyed in

\footnotetext{
228. See County of A llegheny v. A CLU, 492 U.S. 573, 619 (1989) (Blackmun, J., concurring); see also supra note 124 and accompanying text.

229. However, one might also imagine notations in a concert program that would have the opposite effect. For example, if a concert program included unexplained religious symbols or stated in reference to a sacred or even a secular piece of music, "The beauty and ingenuity of this music surely illustrates the infinite creative power of God," the program would have the effect of endorsing religion. Such statements or symbols would emphasize the music not as an independent aesthetic entity, but rather, as a vehicle for divine praise and religious worship. Cf. Sease v. School Dist., 811 F. Supp. 183, 189-90 (relying in part on concert program "replete with religious symbols, quotes from scripture, and references to 'Jesus' 'God', and 'Our Savior'" in concluding that school gospel choir's activities were religious in nature for Equal A ccess Act purposes). However, including such unconstitutional statements or symbols would be distinguishable from including the text of the pieces on the program. It is a standard concert practice to include in concert programs the text of pieces performed, especially translations of pieces performed in foreign languages. The inclusion of such text, as opposed to unrelated biblical verse for example, would not have the effect of endorsing religion but would underscore the musically significant relationship between music and text.
} 
the program. A fairly understood explanation for such a performance could be that the concert intended to create a "historical performance." For example, many Baroque orchestras use original instruments in order to present a performance that recreates, as closely as possible, the sound of the music as it was originally heard by Baroque audiences. In addition, choirs that specialize in renaissance music, such as madrigals, might perform in traditional renaissance attire. In the same way, a chorus might process with candles in singing a Gregorian chant in order to recreate conditions of original performance. Such a performance could be constitutional if program notes explained the musical and historical significance of such performance conditions as aspects of the performance. By emphasizing the music as an independent aesthetic entity, program notes would serve to negate any effect of endorsement of religion. ${ }^{230}$

Similarly, the rehearsal context in this hypothetical does not convey a message of endorsement. The factors that might contribute to a rehearsal context include the statements made by and the teaching style of the choir director. In this hypothetical, the teacher does not proselytize. She does not discuss the virtues of a particular religion or of religion in general. She does not encourage students to adopt a religion. The teacher's unvoiced inner hope to

230. The MENC has made a similar suggestion, stating: "It is important to communicate that music learning, not religious indoctrination, is the motivation in choosing repertoire. One way to reinforce this is to list the music concepts/skills associated with each song in a printed program." MENC 1996 Position Statement, supra note 62, at 3.

Further, as previously discussed, see supra note 97 , there is disagreement within the Court as to whether the quantum of knowledge attributed to the reasonable observer should include a collective knowledge of community history and context of the government practice at issue. By educating audiences as to the musical reasons for the performance and by focusing audience attention on musically relevant aspects of the work, program notes serve to equalize this quantum of community knowledge attributable to the reasonable observer. By making collective musical knowledge explicit to the actual audience, program notes would make a particular performance less likely to convey an effect of endorsement under either view of the quantum of knowledge attributable to the reasonable observer.

Finally, in addition to negating any effect of endorsement, program notes may address a greater social problem. If after a public school choral concert, the only thing two people in an audience can discuss is whether the concert was "too Christian" or "too secular," the problem may not be constitutional but may point to the greater social issue that audiences do not know what to listen for. As the prevalence of MTV and the disparity of "classical" to "rock" radio stations suggests, widespread exposure to "classical" music is not commonplace. Program notes may serve to appropriately focus audience attention on musically relevant aspects of the work, and encourage discourse and dialogue about musical aspects of the performance. 
effect such a result, unaccompanied by proselytizing conduct, does not render the rehearsal context an unconstitutional establishment of religion. Certainly, if the teacher were to explicitly encourage students to adopt a particular faith, she would be endorsing religion in violation of the Establishment Clause. Similarly, if the teacher were to condition proper understanding or performance of the music on acceptance of the textual message-for example, by saying, "Y ou must accept the fact that God gave his only begotten son for the forgiveness of our sins in order to understand and present a convincing performance of this piece" - there would be the effect of endorsing religion and a violation of the Establishment Clause.

However, in analyzing whether the use of sacred choral music in a particular rehearsal context has the effect of endorsing religion, one must also be mindful of the important relationship between music and text that is central to composition, interpretation, and performance. A s such, within the context of rehearsing a piece of sacred choral music, many statements that might seem-in the abstract-to have an effect of endorsing religion do not have such effect. For example, a teacher's statement, such as "B ring out the glory in this line 'Glory to God,'" might seem to endorse religion. However, in the context of rehearsing "Glory to God" from $H$ andel's $M$ essiah, this statement is not an endorsement of religion. The Bauchman court similarly, and correctly, found that the choir director's statements encouraging students to "feel the music" and to "listen to the words" did not have the effect of endorsing religion. 231

The statements made by the choral directors in both Bauchman and this hypothetical do not endorse religion because, in the context of rehearsal, such statements can be fairly understood as part of a religiously-neutral, valid pedagogical technique. This pedagogical technique emphasizes tone painting, a common compositional device in setting text to music, whereby the composer aurally illustrates the meaning of the text in the music. ${ }^{232}$ It is

231. See Bauchman v. West High Sch., Civ. No. 95-C-506G, 1996 WL 407856, at *7 (D. Utah May 30, 1996). A Ithough the Bauchman court reached the correct result, the court did not elaborate as to why such statements could not be fairly understood to endorse religion. See id.

232. Tone painting could involve anything from having the melodic line ascend when the text describes the sky, to using dissonant harmonies when the text expresses a concept such as hate or sadness, to using major tonic chords when the text expresses happi- 
pedagogically necessary for a music teacher to discuss the meaning of the text insofar as that meaning relates-or does not relate if the composer is using sarcasm or irony-to the music. Encouraging students to "feel the music" or to reflect the meaning of the text through the tone they produce vocally or through their facial expression does not demonstrate endorsement of religion but, rather, demonstrates artistic sensitivity to the relationship between music and text. Directing students to "feel the music" or to consider the underlying text is distinguishable from directing students to "believe the text," which would be an endorsement. Indeed, a choir singing Messiah excerpts would look and sound ridiculous singing "Behold the lamb of God that taketh away the sins of the world," set in somber $G$ minor to the slow tempo $L$ argo, with a bright, happy tone and grinning facial expressions. Similarly, a choir would look and sound equally ridiculous singing, "Glory to God in the Highest," set in bright D major with prominent brass orchestration, to the sprightly tempo Allegro, with a dark, gloomy tone and sad facial expressions. ${ }^{233}$ A music teacher would even be artistically sensitive to the meaning of the text by encouraging students to think of something other than its literal meaning in order to evoke the appropriate tone; for example, in rehearsing "Glory to God," the teacher might direct students to reflect in their tone and expression whatever thought gives them joy or happiness. Therefore, encouraging students to "feel the music" could reasonably be interpreted, not as endorsing the textual message, but as encouraging any manner of feeling which is consistent with the character of the music, whether that feeling is related to the literal

ness. See Schwadron, supra note 53, at 162 ("Conductors sometimes try to produce special musical effects by spoken word-pictures (e.g. 'Can you get the hate of the crowd into that 'vah'?' .....") (citations omitted); NATTIEZ, supra note 12, at 125-26 tbl. 5.1 (collating interpretations of tonal symbolism from works of four composers and demonstrating usage of certain keys to convey similar emotions); DERYCK COOKE, THE LANGUAGE OF MUSIC 14-15 (1959) (citing numerous examples of composers using musical motives to express certain emotions, including the minor sixth falling to fifth to express anguish, the phrase 1-3-5-6-5 in a major scale to express joy, and minor keys to express tragedy).

233. See COOKE, supra note 232, at 14-15. Cooke describes the relationship between music and text and argues that "[w]ithin the orbit of tonality, composers have always been bound by certain expressive laws of the medium." Id. at 15. He asks, "Did anyone ever set the Resurrexit of the Mass to slow, soft, minor music? Or the Crucifixus to quick, loud, major strains? Try singing the word 'Crucifixus' to the music of Handel's $\mathrm{H}$ allelujah Chorus, or the word 'Hallelujah' to the music of the Crucifixus in Bach's B minor Mass!" Id. at 14. 
meaning of the text or not. In this hypothetical, then, the directive "feel the music," given in the context of rehearsing the Messiah excerpts, does not have the effect of endorsing religion.

Based on the foregoing, in this hypothetical performance and teaching context, the inclusion of $\mathrm{H}$ andel's Messiah in the curriculum is constitutional. A Ithough the music teacher has an unvoiced religious motivation in addition to her secular motivation for selecting the piece, this purpose is not as probative of constitutionality as the effect of using the music. It is the effect, dependent on context, that is most determinative. Given the relevant factors of these performance and teaching contexts, the use of $\mathrm{H}$ andel's M essiah does not have the effect of endorsing religion.

\section{B. Performance at G raduation Ceremony}

The high school chorus performs one selection as part of the high school graduation ceremony. The choir director selects An Irish Blessing by Dede Duson, a four-part a cappella piece from the current repertoire of the chorus. The text reads:

$M$ ay the road rise to meet you;

$M$ ay the wind be always at your back;

$M$ ay the sun shine warm upon your face, and the rain fall soft upon your fields;

A nd until we meet again, may God hold you in the palm of $\mathrm{H}$ is hand. ${ }^{234}$

Before the choir performs, the principal announces to the audience, "We will now hear a musical selection from the chorus." The names of the piece and the composer, and the dates of the composer's birth and death, appear in the graduation program. The choir performs the piece in the middle of the ceremony, while the audience is seated. The audience applauds at the conclusion of the piece.

The performance of music at ceremonial occasions is commonplace and even expected. ${ }^{235}$ There could be many secular purposes in performing this piece at a graduation ceremony, such as underscoring the collective nature of the ceremony or merely showcasing the school choir (lest choir members be denied the same opportunity to perform at graduation that is provided to the

234. Dede Duson, An Irish Blessing (Neil A. Kjos Music Co., 1982).

235. See STORR, supra note 10, at 23-24. 
school band, which will almost certainly play Pomp and Circumstance). However, in considering the constitutionality of the above hypothetical, the more determinative inquiry is the effect of this performance, which is determined by context.

In determining whether this hypothetical graduation performance of $A n$ Irish Blessing has the effect of endorsing religion, we must first address whether, in light of the Supreme Court's decision in Lee $\mathrm{v}$. Weisman, ${ }^{236}$ hearing or singing a piece of sacred choral music in the context of a public school graduation is a "religious exercise." Although the Court's holding in Weisman forbids the use of prayers in the public school graduation context, Weisman may be distinguished from the I rish Blessing hypothetical on the basis of the differences between prayers and choral music. In declaring state-directed prayer in public schools to be violative of the Establishment Clause, the Engel Court relied on an "always religious" definition of prayer. ${ }^{237}$ This holding was reaffirmed by the Court in Weisman. ${ }^{238}$ Therefore, state-directed prayer is clearly constitutionally impermissible under the Establishment Clause. On the other hand, as the conflict between music and religion in the context of the worship service reveals, ${ }^{239}$ unlike prayer, sacred choral music is not "always religious." While sacred choral music may be a vehicle for religious worship and divine praise, it may simultaneously be a secular aesthetic entity that in no way depends on the performer's or the listener's endorsement of the textual message.

The text at issue here, in particular the line, "M ay God hold you in the palm of his hand," and the title, "A n Irish Blessing," could be characterized as a "supplication for the blessings of the A Imighty." ${ }^{240}$ If these words were to be recited in the graduation ceremony, there would almost certainly be a state-directed religious exercise and an effective endorsement of religion. If the words were to be recited, the hypothetical would come closer to the facts of Aldine, which involved a school-composed prayer that

236. 505 U .S. 577 (1992).

237. Engel v. Vitale, 370 U.S. 421, 424 (1962).

238. See Weisman, 505 U.S. at 603.

239. See supra Introduction (discussing historical conflict concerning use of sacred music in worship service and fear of religious leaders that music in worship service will be appreciated for its secular rather than its religious qualities).

240. Engel, 370 U.S. at 424. 
was both recited and sung by the school community. ${ }^{241}$ The recitation practice by the school community could cause any subsequent singing to be understood as a parallel to the recitation and thereby as a promotion of religious worship and divine praise. However, in the Irish Blessing hypothetical, the lyrics to the song are not recited in the graduation ceremony.

In addition, the religious aspects of the text do not require the conclusion that the song-a combination of music and text-is a prayer, nor that the singing of the song is an act of worship. A rguably, once music and text are combined, each loses its independent significance and becomes a new entity. Given the inherent duality of music, the presence of a melodic and harmonic line detracts from the independent religious significance of the text. A nd the more complicated the music, the less emphasis on the music as vehicle for religious message and the greater the emphasis on the music as independent aesthetic entity. ${ }^{242}$ This might be the case with the four-part harmony in An Irish Blessing. In E ngel, the Supreme Court also recognized this dual nature of music in asserting that singing a patriotic song in which the composer has professed faith in a Supreme Being is not the equivalent of a "religious exercise":

There is of course nothing in the decision reached here that is inconsistent with the fact that school children and others are officially encouraged to express love for our country . . . by singing officially espoused anthems which include the composer's professions of faith in a Supreme Being. ... Such ... ceremonial occasions bear no true resemblance to the unquestioned religious exercise that the State of $\mathrm{New} \mathrm{Y}$ ork has sponsored in this instance. $^{243}$

The Court's statement ultimately relies on the dual nature of the music at issue. While a patriotic anthem that mentions a divine being might, for the composer, be a profession of faith in a Su-

241. See Doe v. A Idine Indep. Sch. D ist., 563 F. Supp. 883, 885 (S.D. Tex. 1982).

242. The historic conflict between music and religion supports this argument:

The fear of the European church leaders of the misuse of music was vastly heightened with the development of polyphony. Ornamentation and highly melismatic settings... had long threatened the clarity of the words. But the collisions of different phrases or word fragments and the musical cross-rhythms of $N$ otre Dame polyphony were a further attack on verbal clarity.

PERRIS, supra note 8, at 141.

243. Engel, 370 U.S. at 435 n.21. 
preme B eing, the same anthem might, for the singer or listener, be a secular expression of patriotic love. These dual perceptions are relevant to the legal analysis of effect and are anticipated by a holistic theory of music, under which the singer's interpretation and the listener's perception contribute to the very creation of the musical work.

A nother factor that distinguishes the context of singing $A n$ Irish Blessing from the facts of Weisman is the absence of clergy. ${ }^{244}$ The state is not "entangling" itself with a religious leader and directing the content of the religious leader's prayer by inviting a religious leader to speak and by providing that person with guidelines for suitable prayer composition. A Ithough it may be argued that, despite the absence of the clergy, selection by the choir director is the functional equivalent of the state composing the school prayer in Engel or the state compositional involvement in Weisman, this argument requires finding that a song is equivalent to prayer. However, as argued above, a piece of music, even that with a sacred text, differs from a prayer in that it is not "always religious." The performance of a piece of music, unlike a prayer, is not by its very nature a "religious exercise" and is distinguishable from an "act of worship." A member of the clergy is not "performing," and the reasonable perception of listeners is that they are participating in an "act of worship." A choir singing a song is performing and can be objectively perceived by its listeners to be performing. These aesthetic and functional differences, including the claim or disclaimer of reality by the artifice of performance and the differing expectations of the audience, distinguish a song from a prayer.

These differences between song and prayer, in light of Engel and Weisman, inform the "effects" analysis. A s with the first hypothetical, the context of singing A $n$ Irish B lessing is a public performance which, by its very nature, negates any effect of endorsement. The audience is not being asked to recite the text of the song; the audience is not being asked to stand while an individual

244. There is a split of authority in the Circuit Courts as to whether student-led prayer at graduation is constitutional. See ACLU of New Jersey v. Black Horse Pike Regional Bd. of Educ., 84 F.3d 1471 (3rd Cir. 1996) (striking policy allowing majority of students to decide whether or not to have prayer at public school's graduation ceremony; Jones v. Clear Creek Indep. Sch. Dist., 977 F.2d 963 (5th Cir. 1992), cert. denied 113 S. Ct. 2950 (1993) (upholding policy allowing majority of students to decide whether or not to have prayer at public school's graduation ceremony). 
reads the text of the song. Those uses would come closer to a religious exercise-to the facts of Weisman or Engel-and could reasonably be perceived as an "endorsement." Rather, in this hypothetical, the audience remains seated while a choral group performs. The fact that the audience claps at the end of the song further emphasizes the performance context. A nd this performance context easily distinguishes this hypothetical from the unconstitutional singing of the school prayer in Aldine. ${ }^{245}$ In Aldine, there was no performative disclaimer of reality. The prayer was sung or recited not by the school chorus but by the school community. ${ }^{246}$ The text specifically referred to reality- "please bless our school"247-and the text was incorporated into the everyday school routine through its posting in raised black letters on the wall of the gymnasium. ${ }^{248}$

There is a final aspect of the performance context of this hypothetical that bears on this "effect" analysis: the placement of the song within the program. Placing this song at the end of the ceremony may alter the context. A rguably, the effect of placing the song at the end of the ceremony might be that the song could reasonably be viewed not as a performance, but as a prayer, in lieu of a benediction. ${ }^{249}$ In this case, however, since the song is performed in the middle of the ceremony, the placement of the song has no ritualistic religious significance. It is simply a performance of a musical selection within the ceremony. Moreover, it is indicated as such and emphasized for its musical identity through the graduation program and through the principal's introduction.

In this hypothetical, the performance of An Irish Blessing brings art into the ceremony and makes neither any claim of reali-

245. See Aldine, $563 \mathrm{~F}$. Supp. at 884 (concerning the singing of words of prayer by the entire student body at sporting events, pep rallies, and graduation ceremonies).

246. See id.

247. Id. (emphasis added).

248. See id.

249. A rguably, the Duncanville court should have considered whether the singing of the choir's theme song at the end of class every Friday and on bus rides home from performances would similarly convey an effect of endorsement, especially given the fact that there is no performative disclaimer of reality and no readily understandable teaching purpose to repeatedly singing the song at conclusionary times. See Doe v. Duncanville Indep. Sch. Dist., 70 F.3d 402, 404 (5th Cir. 1995) (concerning the singing of a Christian theme sung by the choir at the end of class on Fridays, at the end of some performances, and at choral competitions); see also infra notes 252-60 and accompanying text (discussing a third hypothetical). 
ty nor any claim that the choir director, performers, school administrators, or listeners endorse any religious aspects of the text. While the singing of these words in a worship service might be akin to prayer, the singing of these words in the context of a performance is not a prayer. As with the first hypothetical, by presenting the song as music, the context of performance negates any message of endorsement. In this case, the placement within the order of the ceremony, the inclusion in the program, and introduction in such a way as to emphasize the musical significance of the performance all contribute to the performance context. To further emphasize this musical significance, the choir director could write a short program note, making explicit the musical significance of the piece and the musical reasons for the selection. Even without such notes, however, the singing of An Irish Blessing by the school choir is a musical performance that serves as an appropriate adjunct to the graduation ceremony, reinforcing the communal and collective aspect of the event insofar as the song is sung by a collective group-the school choir. Thus, the performance of the song in the context of this hypothetical does not have the effect of endorsing religion.

\section{Designating and Singing a Theme Song}

The high school choir designates a four-part arrangement of George Gershwin's "Oh Lawd, I'm On My Way," from Porgy and $\mathrm{Bess}^{250}$ as its theme song. The song is recognized as such by the school community, including the choir director. As theme song, the piece is performed in every concert and indicated as "theme song" in programs. The piece is also sung, under the direction of the choir director, at the end of class on Fridays, and on bus rides home after concerts and competitions.

\footnotetext{
250. The text reads:

Oh, Lawd, I'm on my way.

I'm on my way to a Heav'nly Lan',

I'll ride dat long, long road,

If you are there to guide my han'.

Oh Lawd, I'm on my way.

I'm on my way to a Heav'nly Lan' oh Lawd.

It's a long, long way, but you'll be there to take my han'.

George Gershwin, Oh, Lawd, I'm On My Way, from PORGY AND BESS (Gershwin Publishing Corp., 1935).
} 
In considering whether this use of sacred music has the effect of endorsing religion, there are two features of this hypothetical that are especially problematic: 1) the designation of the song as theme song and the affect of this designation on the performance context; and 2) the singing of the song at the end of class on Fridays and on bus rides home after concerts and competitions.

The designation of "Oh Lawd, I'm On My Way," as theme song alters the performance context such that performing this song even in a concert hall could convey a message of endorsement. Consistent with the previous hypotheticals, it is not the selection of the piece as part of the choir's repertoire that is constitutionally problematic, nor is it the fact that the piece is performed with frequency. If this piece was performed in every concert but was not labelled as theme song, there would arguably not be a message of endorsement. As stated above, the inherent artifice and disclaimer of reality in a true performance context can negate any effect of endorsement. However, the designation of the song as theme song alters the performance context and may have the effect of endorsing religion.

The choir's designation of the song as their "theme song" denotes the concept of group identification rather than the performative notion of artifice. Even if one accepts that there could be pedagogical benefits to designating a theme song, ${ }^{251}$ these benefits cannot be achieved through a method that has the effect of endorsing religion. The notion of recognizing insiders and outsiders on the basis of religion, embodied in the endorsement test, is contrary to the Establishment Clause. This recognition of insiders and outsiders is inherent in the concept of group identity. The theme song unifies the choir, and the choir identifies the group by the song; moreover, the community identifies the group with the song. U sing religious symbolism to identify a group could convey a message of endorsement to the reasonable observer. That the students have designated the song as their "theme song" does not lessen the effect of endorsement, given that state actors-including the choir director-continue to recognize and to identify the song as such in concert programs.

251. O ne benefit might be that a theme song builds community by making students feel more invested in their choir. As a result, students may sing with the choir for a longer period of time, further developing their musical skills and strengthening the overall sound and ability of the choir. 
Giving the song the label of theme song and identifying the chorus with that song also lessens the theatrical artifice aspect of the performance. When a group is identified by a particular sacred choral song, it is more likely that the members of the group will be viewed as endorsing the meaning of that song when they sing the song-even if the performance takes place in a concert hall. There is no meaningful disclaimer of reality.

However, there could conceivably be a situation where having a sacred song as a "theme song" did not convey a message of endorsement. For example, if the choir selected a particular sacred song as a "theme song" because of the song's independent secular significance to the choir, there might not be an effect of endorsement. Perhaps the choir won several choral competitions for its performance of the song and, as a result, chose the song for its "theme song." If this independent secular significance was explained in the program or known to the community, then even if the group was identified by the song, and even if this identification lessens the performative artifice somewhat, there might not be an effect of endorsement. In this example, the group would not be perceived to identify with the religious message of the song but with an independent secular significance of the song.

Nonetheless, in this hypothetical, in addition to the labeling of "Oh Lawd, I'm On My Way," as "theme song," the singing of this song (whether designated as "theme song" or not) at the end of class on Fridays and on bus rides home from competitions and concerts could have the effect of endorsing religion. In this hypothetical, the effect or "perceived purpose" of singing the song at the end of class every Friday and on bus rides after concerts may be fairly understood as prayer, a solemn avowal of divine faith and supplication for the blessings of the A Imighty. In other words, there is no performative disclaimer of reality. The singing of the song in these contexts does not have a fairly understood non-religious purpose. It does not seem to be for rehearsal purposes; in this hypothetical, the teacher is not rehearsing the piece nor perfecting the group's interpretation or critically evaluating their singing. The group is not singing the song at the beginning of rehearsal or before competitions as a warm-up or focusing device. R ather, in its repetition at significant conclusionary times, the context of the use of this theme song has the attributes of a religious ritual or exercise. Given the context, which emphasizes the song as a vehicle for religious worship rather than as an independent aes- 
thetic entity, one would be hard pressed to find an alternative way in which such singing could be understood.

This analysis is clearly contrary to the Fifth Circuit's opinion in Doe v. Duncanville Independent School District, ${ }^{252}$ where the court held that designation of a sacred song as "theme song" did not have the purpose or effect of endorsing religion. ${ }^{253} \mathrm{H}$ owever, the Fifth Circuit's finding of constitutionality is problematic for many reasons. First, in determining that there were fairly understood secular purposes to maintaining the song as theme song, the court accepted the choir director's assertions that the song is useful for teaching students to sight-sing and to sing a cappella and the piece is a "good piece of music ... by a reputable composer." 254 Both of these justifications have no relationship with the designation of the song as "theme song" rather than one of many songs in the repertoire. The justification that the piece is useful for teaching sight-reading is especially irrelevant, because any piece can be useful in teaching sight-reading, and, if the purpose is to teach sight-reading, there is no reason to repeatedly sing the piece once it has been sight-read.

Second, the court mischaracterized the practical effects of designating the song as "theme song." The court stated that there were two practical effects, that the piece is "sung often and it is carried over from year to year." ${ }^{255}$ The court only addressed these two effects and found that, given the prevalence of sacred choral music in the repertoire, "[l]imiting the number of times a religious piece of music can be sung is tantamount to censorship and does not send students a message of neutrality." ${ }^{256}$ While the singing of the song in Duncanville $e^{257}$ could be constitutional were those the only practical effects of designating a sacred choral song as theme song, the practice appears unconstitutional on the basis of facts cited in the opinion but not addressed by the Fifth Circuit. The court never addressed the singing of the song at the end of class on Fridays nor the singing of the song on bus rides home from performances, although these important practical effects of

252. 70 F.3d 402 (5th Cir. 1995).

253. See id. at 407.

254. Id.

255. Id.

256. Id. at 408.

257. See id. at 404. 
designating the song as theme song are noted in the facts. ${ }^{258} \mathrm{Be}$ cause of this oversight, the court never addressed the arguments raised here-that such a use of the song, in those particular contexts, does effectively endorse religion in its similarity to religious exercise and ritual. Further, while the court did consider the concept of group identity inherent in the nature of designating a theme song, the court failed to consider group identity in relation to the performance context. ${ }^{259}$ The court only considered the concept of group identity from the perspective of choir members and did not consider how the concept of group identity affects the objective perceptions of the audience in the context of a performance. ${ }^{260}$

Despite the Fifth Circuit's holding in Duncanville, the designation of the sacred choral song as "theme song" in this hypothetical does convey group identity and thereby alters the performance context so as to convey a message of endorsement. And the director's leading the singing of the song, on Fridays and on bus rides home after concerts and competitions, conveys a ritualistic emphasis on religious exercise rather than on aesthetics. To the reasonable observer, these uses could easily carry a message of endorsement. Both of these factors on their own, and certainly in conjunction, could make the use of sacred music in this hypothetical unconstitutional.

\section{CONCLUSION}

Music is a medium of tremendous emotive and persuasive power. The combination of this tremendous power with vocal music's inherently dual nature - that vocal music can simultaneously be a vehicle for the promotion of a textual message as well as an independent aesthetic entity that in no way depends on the performer's or the listener's endorsement of the textual messagecauses tension between music and religion. In the choirs of the public schools, this tension invites Establishment Clause controversy.

258. See id.

259. See id. at 408 n.8. Consideration of group identity in relation to the performance context was deemed relevant by Justice 0 'Connor in her articulation of the "endorsement test" in L ynch v. Donnelly. See supra notes $91-92$ and accompanying text.

260. See Duncanville, 70 F.3d at 408 n.8. 
In defending the place of sacred music within public school curricula, it has been asserted that

[i]f it is possible to study Communism without indoctrination or to examine the ills of contemporary society without promoting the seeds of revolution, then it must also be possible to study sacred music (with performance-related activities) without parochialistic attitudes and sectarian points of view. ${ }^{261}$

This Note has argued that it is possible to study sacred music in the public schools without effectively endorsing religion or violating the Establishment Clause. Whether a particular use of sacred choral music has the effect of endorsing religion is dependent on context. A s composer-philosopher J ohn Cage has remarked, "[T] ]he work of art ... is finished by the observer." ${ }^{262}$ For some, sacred music can be a vehicle for promoting a religious message-a religious symbol. Music educators must be "mindful of the power of a symbol standing alone and unexplained." ${ }^{263}$ M usic educators can and must take steps to ensure that a particular context does not have the effect of endorsing religion, by emphasizing the independent, secular identity of this music. Stressing the musical significance of a particular rehearsal technique or preparing program notes for performances can negate any message of endorsement. Such pedagogical techniques may also underscore the identity of the music as an independent, secular, aesthetic entity that in no way depends on the performer's or the listener's endorsement of the textual message.

Teaching and performing sacred choral music in contexts that emphasize the independent aesthetic identity of this music is consistent with the purpose of the Establishment Clause and of the First A mendment-protecting freedom of individual conscience. Exposing students to sacred music does not, in itself, violate the individual conscience. Exposing students to sacred music as part of a comprehensive music education curriculum values the professional judgment of music educators, broadens the educational experience and presents a complete and accurate view of the nature of art. It is the censorship of sacred choral music that presents a

261. Schwadron, supra note 53 , at 166 .

262. MUSICAGE, supra note 12 , at 67 (citing the philosophy of the artist Duchamp).

263. Capital Square Review \& Advisory Bd. v. Pinette, 115 S. Ct. 2440, 2466 (1995) (Stevens, J., dissenting). 


1168 DUKE LAW JOURNAL [Vol. 46:1111

selective, revisionist view of history and stunts the educational experience. 